OPEN ACCESS

Edited by:

Con Stough,

Swinburne University of Technology,

Australia

Reviewed by:

Muzamil Ahmad,

Indian Institute of Integrative Medicine,

India

Luca Ferraro,

University of Ferrara, Italy

Boyer D. Winters,

University of Guelph, Canada

*Correspondence:

Ashok Kuma

kash@ufl.edu

Specialty section:

This article was submitted to

Neuropharmacology,

a section of the journal

Frontiers in Neuroscience

Received: 05 September 2015 Accepted: 25 November 2015

Published: 16 December 2015

Citation:

Kumar A (2015) NMDA Receptor

Function During Senescence: Implication on Cognitive Performance.

Front. Neurosci. 9:473.

doi: 10.3389/fnins.2015.00473

\section{NMDA Receptor Function During Senescence: Implication on Cognitive Performance}

\author{
Ashok Kumar * \\ Department of Neuroscience, Evelyn F. and William L. McKnight Brain Institute, University of Florida, Gainesville, FL, USA
}

N-methyl-D-aspartate (NMDA) receptors, a family of L-glutamate receptors, play an important role in learning and memory, and are critical for spatial memory. These receptors are tetrameric ion channels composed of a family of related subunits. One of the hallmarks of the aging human population is a decline in cognitive function; studies in the past couple of years have demonstrated deterioration in NMDA receptor subunit expression and function with advancing age. However, a direct relationship between impaired memory function and a decline in NMDA receptors is still ambiguous. Recent studies indicate a link between an age-associated NMDA receptor hypofunction and memory impairment and provide evidence that age-associated enhanced oxidative stress might be contributing to the alterations associated with senescence. However, clear evidence is still deficient in demonstrating the underlying mechanisms and a relationship between age-associated impaired cognitive faculties and NMDA receptor hypofunction. The current review intends to present an overview of the research findings regarding changes in expression of various NMDA receptor subunits and deficits in NMDA receptor function during senescence and its implication in age-associated impaired hippocampal-dependent memory function.

Keywords: aging, hippocampus, oxidative stress, NMDA receptor, GluN2A, GluN2B, learning, spatial memory

\section{INTRODUCTION}

$\mathrm{N}$-methyl-D-aspartate (NMDA) receptors represent one of the ligand-gated non-selective ionotropic glutamate receptors (iGluRs), which are present in high density within the hippocampus and the cerebral cortex and play pivotal physiological and pathophysiological roles in the central nervous system (Cotman and Monaghan, 1989; Cotman et al., 1989). NMDA receptors along with other iGluRs, such as $\alpha$-amino-3-hydroxy-5-methylisoxazole-4-isoxazopropionic acid (AMPA) and Kainate, are critical for the rapid regulation of synaptic plasticity including longterm potentiation and long-term depression, which are important cellular correlates for learning and memory function (Morris et al., 1986; Collingridge, 1987; Mondadori et al., 1989; Morris, 1989; Mondadori and Weiskrantz, 1993; Lisman et al., 1998; Martin et al., 2000). Recently, the International Union of Pharmacology Committee on Receptor Nomenclature and Drug Classification has adopted and published new guidelines to standardize the nomenclature and classification of NMDA receptor subunits (Collingridge et al., 2009). We will use this recent nomenclature to refer to various NMDA receptor subunits. These receptors are hetero-tetrameric protein complexes composed of two classes of related subunits from seven homologous genes, GluN1, GluN2A-GluN2D, and GluN3A-GluN3B (Moriyoshi et al., 1991; Kutsuwada et al., 1992; Meguro et al., 1992; Monyer et al., 1992; Laube et al., 1998; Dingledine et al., 1999; Cull-Candy et al., 2001; Figure 1). 


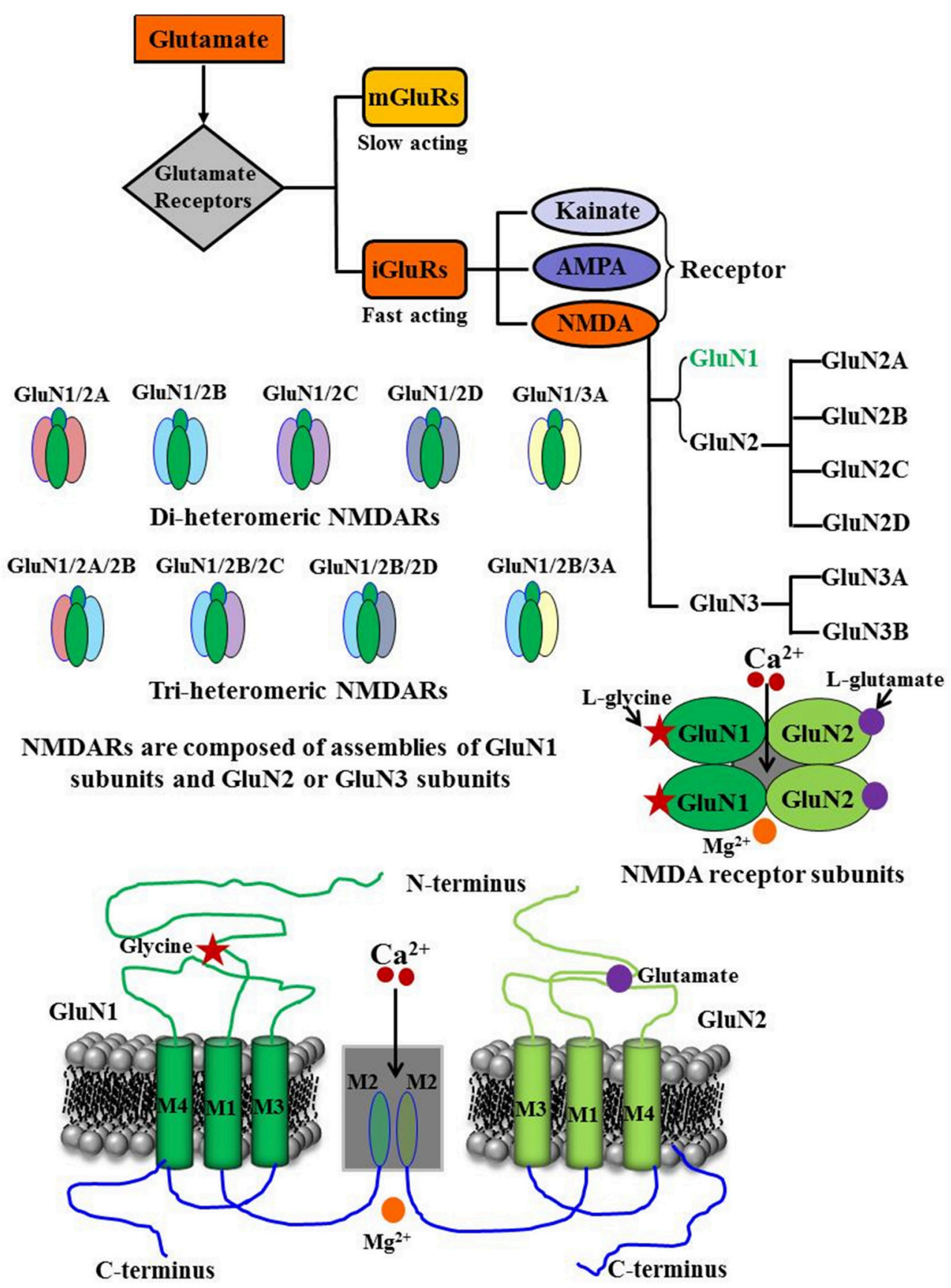

FIGURE 1 | Schematic model of the NMDA receptor and its subunit configuration. NMDA receptors represent one of the inotropic glutamate receptors, which are composed of assemblies of GluN1 subunits and GluN2 and or GluN3 subunits. Functional NMDA receptors are composed of two GluN1 subunits and two GluN2A-D subunits; GluN3 subunits (GluN3A and GluN3B), without involving other GluN2 subunits, can assemble with GluN1 subunits to form active receptor. GluN1 subunits carry the co-agonist glycine binding site while glutamate binds to GluN2 subunit. $\mathrm{Mg}^{2+}$ blocks the $\mathrm{Ca}^{2+}$ permeable pore. All of these subunits of NMDA receptor share a common membrane topology, a large extracellular amino-terminal domain, three transmembrane segments (M1, M3, and M4), a re-entrant pore loop (M2), and an intracellular cytoplasmic C terminal domain.

The majority of NMDA receptors are assemblies of two GluN1 subunits, the ubiquitously expressed and obligatory subunit, and two GluN2A-D subunits, a modulatory subunit. In addition, GluN3 subunits (GluN3A and GluN3B), without involving GluN2 subunits, can assemble with GluN1 subunits to form functional receptors (Sucher et al., 1995; Laube et al., 1998; Al-Hallaq et al., 2002; Schüler et al., 2008; Low and Wee, 2010). All NMDA receptor subunits share a common membrane topology: a large extracellular amino-terminal domain, three transmembrane segments (M1, M3, and M4), a re-entrant 
pore loop (M2), and an intracellular cytoplasmic C terminal domain. The re-entrant M2 loop is part of the channel pore, which mediates the magnesium blockade and determines calcium permeability of the channel (Figure 1; Hollmann and Heinemann, 1994; Dingledine et al., 1999; Madden, 2002). For more details about the structure of NMDA receptor subunits, readers are requested to consult excellent review articles published recently (Magnusson et al., 2010; Traynelis et al., 2010; Magnusson, 2012; Monaghan et al., 2012; Flores-Soto et al., 2013; Sanz-Clemente et al., 2013; Wyllie et al., 2013; Shipton and Paulsen, 2014; Burnashev and Szepetowski, 2015; Glasgow et al., 2015; Zhu and Paoletti, 2015).

The activation of NMDA receptor requires binding of a ligand (glutamate) to the GluN2 subunits, membrane depolarization to remove the $\mathrm{Mg}^{2+}$ block of the channel, and binding of an essential co-agonist, glycine to the GluN1 subunits. For maximal activation of the NMDA receptor, binding of both glutamate and glycine are thought to be required. Results have demonstrated that $\mathrm{D}$-serine might represent another physiological co-agonist of the NMDA receptor as it can bind at the glycine-binding site (Hood et al., 1989; Priestley et al., 1995; Mothet et al., 2000; Panatier et al., 2006; Labrie and Roder, 2010). NMDA receptors have slow gating kinetics (Lester and Jahr, 1990). The GluN2A-containing NMDA receptors have higher open channel probability and faster deactivation rate than GluN2B-containing receptors (Vicini et al., 1998; Chen et al., 1999; Erreger et al., 2005; Erreger and Traynelis, 2005; Gray et al., 2011). Since NMDA receptor is a non-selective cation channel, its activation and opening leads to simultaneous influx of $\mathrm{Na}^{+}$and $\mathrm{Ca}^{2+}$ ions and efflux of $\mathrm{K}^{+}$ions (Dingledine et al., 1999; Chen et al., 2005). However, between the two predominant ionotropic glutamate receptors subtypes, AMPA and NMDA, the NMDA receptors are the most permeable to $\mathrm{Ca}^{2+}$ ions, and the influx of $\mathrm{Ca}^{2+}$ ions contributes to the numerous physiological and pathological actions of the NMDA receptor (Garaschuk et al., 1996).

\section{NMDA RECEPTORS AND SENESCENCE}

NMDA receptors containing GluN2A and GluN2B subunits are highly expressed in the hippocampus and cerebral cortex (Watanabe et al., 1993a,b; Laurie and Seeburg, 1994; Monyer et al., 1994; Laurie et al., 1997; Magnusson, 2000; Magnusson et al., 2007). There is differential spatiotemporal expression and distribution of the various NMDA receptor subunits within the brain suggesting the presence of multiple NMDA receptor populations. The GluN2B subunit is highly expressed throughout the brain during early stages of development and declines at the onset of sexual maturity; GluN2A subunit-containing NMDA receptors increase across the same life span (Laurie and Seeburg, 1994; Monyer et al., 1994; Laurie et al., 1997; Law et al., 2003a,b; Liu et al., 2004). Currently, it is not well known how the multiple subunits of NMDA receptors change with advancing age and how this change may influence the cognitive function. However, evidence is mounting to indicate that advanced age is associated with a decline in NMDA receptor function and subunit expression within brain regions involved in higher brain function including synaptic plasticity, learning and memory
(Gonzales et al., 1991; Pittaluga et al., 1993; Barnes et al., 1997; Magnusson, 1998a; Eckles-Smith et al., 2000; Gore et al., 2002; Liu et al., 2008a; Zhao et al., 2009). Possibly the strongest evidence for impairment in NMDA receptor function comes from physiological studies indicate the NMDA receptor mediated excitatory post-synaptic potentials in the Schaeffer collateral pathway of the hippocampus are reduced by approximately $50-$ $60 \%$ in aged animals (Figure 2; Barnes et al., 1997; Eckles-Smith et al., 2000; Billard and Rouaud, 2007; Bodhinathan et al., 2010a; Brim et al., 2013; Kumar and Foster, 2013; Lee et al., 2014). Most recently, a robust decrease in NMDA receptor mediated synaptic function was also reported in the medial prefrontal cortex of middle aged rats (Guidi et al., 2015a). However, agerelated changes in the amplitude of NMDA-evoked responses were not observed in dissociated cortical neurons suggesting the possibility of regional specificity in the loss of NMDA receptor function over the life span (Kuehl-Kovarik et al., 2003).

A decrease in the level of NMDA receptor protein expression in the hippocampus during senescence has been observed (Bonhaus et al., 1990; Kito et al., 1990; Miyoshi et al., 1991; Tamaru et al., 1991; Wenk et al., 1991; Magnusson, 1995; Magnusson et al., 2006; Billard and Rouaud, 2007; Das and Magnusson, 2008; Liu et al., 2008a; Zhao et al., 2009); further, the decrease has primarily been localized to region CA1 of the hippocampus (Magnusson and Cotman, 1993; Gazzaley et al., 1996; Magnusson, 1998a; Wenk and Barnes, 2000). These studies report reduced binding of $\left[{ }^{3} \mathrm{H}\right]$ glutamate (agonist site), $\left[{ }^{3} \mathrm{H}\right]$ glycine (GluN1 site), $\left[{ }^{3} \mathrm{H}\right] \mathrm{CPP}$ (a competitive antagonist to the L-glutamate binding site), and $\left[{ }^{3} \mathrm{H}\right] \mathrm{MK}-801$ (an open channel blocker) in the hippocampus and cerebral cortex of aged rats. However, others have reported no age-related change in antagonist binding (Kito et al., 1990; Miyoshi et al., 1991; Araki et al., 1997; Shimada et al., 1997) or an increased MK-801 binding in animals with learning and retention deficits (Ingram et al., 1992; Topic et al., 2007). It is interesting to note that MK-801 binds to the hydrophobic channel domain of NMDA receptor, exclusively labeling open channels. Thus, an apparent increase in NMDA receptor channel open time may act as a compensatory mechanism for the decrease in receptor number (Serra et al., 1994; Kumar et al., 2009). However, the majority of reports, including our recent findings, indicate that the net function of the NMDA receptors decreases at CA3-CA1 hippocampal synaptic contacts during senescence (Bodhinathan et al., 2010a; Brim et al., 2013; Kumar and Foster, 2013; Lee et al., 2014). Most recently, we demonstrated a similar decline in NMDA receptormediated synaptic response in the prefrontal cortex of advanced age animals (Guidi et al., 2015a).

\section{MECHANISMS FOR IMPAIRED NMDA RECEPTOR FUNCTION DURING AGING}

\section{Subunit Expression and Composition}

Alteration in expression of specific NMDA receptor subunits might be a potential mechanism for the observed decrease in the NMDA receptor function (Magnusson, 2000). Developmentally, the expression of GluN1, GluN2B, and GluN3A decreases with 

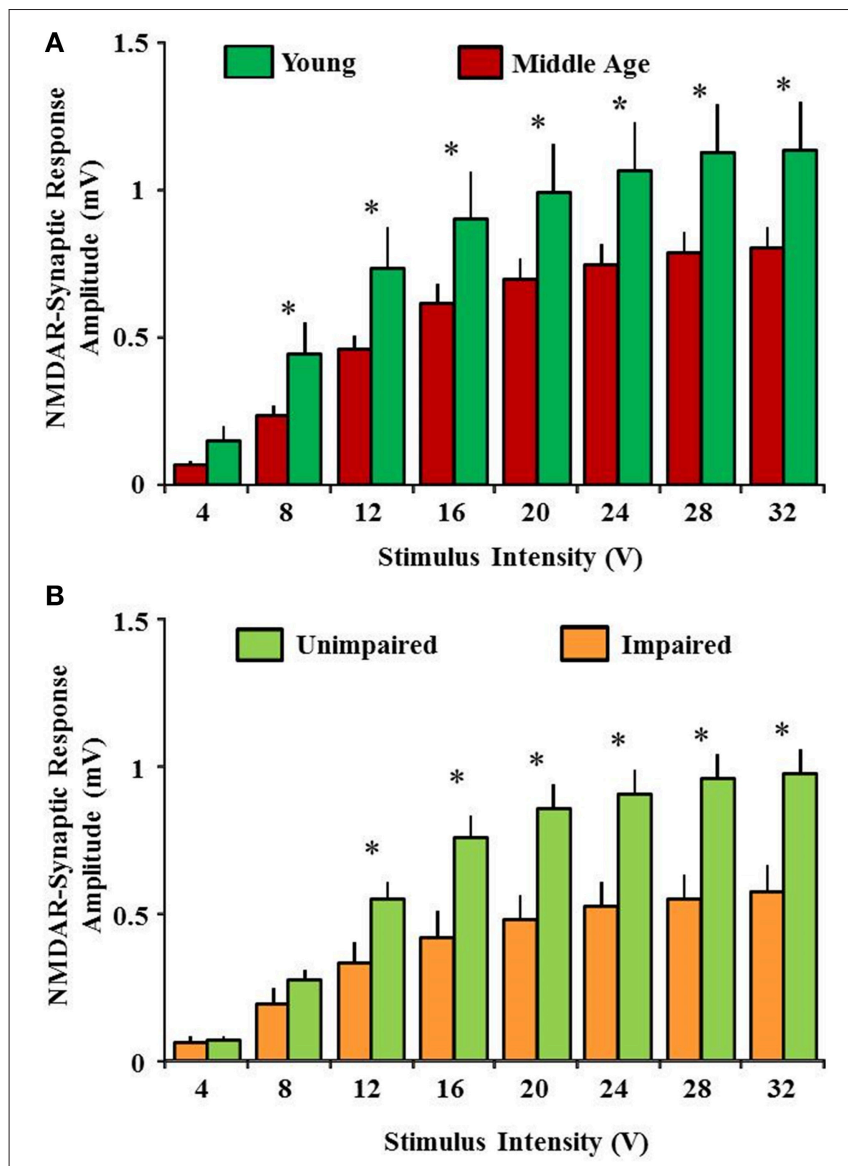

FIGURE 2 | Reduced NMDA receptor-mediated synaptic response with advanced age is associated with impaired cognitive function. (A) Input-output curves for the NMDA receptor-mediated synaptic potentials recorded from CA3-CA1 hippocampal synapse in slices obtained from young (green) and middle age (red) animals. An age-related decrease in the synaptic response was observed. (B) A significant decrease in NMDA

receptor-mediated synaptic response was observed in impaired animals (yellow) when compared with unimpaired (lime green). Cognitive performance was assessed by using Morris swim task. The NMDA receptor-mediated component of synaptic transmission (NMDAR-fEPSP) was obtained by incubating slices in artificial cerebrospinal fluid containing low $\mathrm{Mg}^{2+}(0.5 \mathrm{mM})$, 6,7-dinitroquinoxaline-2,3-dione (30 $\mu \mathrm{M})$, and picrotoxin (10 $\mu \mathrm{M})$. Input-output curves for the NMDAR-fEPSP amplitude $(\mathrm{mV})$ were constructed for increasing stimulation intensities. * indicates significant difference.

age compared to adulthood, while an increase in the expression of GluN2A and GluN3B is reported during development (Low and Wee, 2010). A decrease in the expression of GluN1 protein (Eckles-Smith et al., 2000; Mesches et al., 2004; Liu et al., 2008b) and GluN1 mRNA (Adams et al., 2001) levels in the aged hippocampus has been reported. The amount of $\mathrm{C} 2$ splice variants of GluN1 decline in the hippocampus of aged rats (Clayton et al., 2002a). In contrast, other studies report no age-related decrease in GluN1 protein expression in the whole hippocampus (Sonntag et al., 2000; Zhao et al., 2009). Despite the lack of agreement concerning changes in the expression levels in the hippocampus, other brain regions exhibit a decline in GluN1 mRNA expression during aging. Indeed, senescence-related decrease in the GluN1 mRNA expression has been observed in the medial basal hypothalamus-median eminence (Gore et al., 2002), in the medial and lateral prefrontal cortices (Magnusson et al., 2005), and in the insular, orbital, and somatosensory cortices (Das and Magnusson, 2008).

Results demonstrate age-related changes in the modulatory GluN2 subunits of the NMDA receptor. A decrease in the GluN2A protein expression has been observed in the hippocampus (Sonntag et al., 2000; Liu et al., 2008a), which is not observed in the frontal cortex (Sonntag et al., 2000). Furthermore, GluN2A mRNA expression was reported to decline in the ventral hippocampus (Adams et al., 2001). In contrast, other studies report no significant change in the GluN2A protein expression levels in the hippocampus and cortex (Sonntag et al., 2000; Martínez Villayandre et al., 2004). GluN2B subunit of the NMDA receptor is most affected by the aging process (Magnusson, 2000; Ontl et al., 2004; Magnusson et al., 2007; Zhao et al., 2009); the expression of GluN2B protein (Clayton and Browning, 2001; Mesches et al., 2004; Zhao et al., 2009) and GluN2B mRNA (Adams et al., 2001; Clayton and Browning, 2001; Magnusson, 2001) decline in the hippocampus with advanced age. This effect may be region specific since a decline in GluN2B protein is not observed in the frontal cortex (Sonntag et al., 2000). In contrast, GluN2B mRNA decreases in the frontal cortices of aging macaque monkeys, but not in the hippocampus (Bai et al., 2004). Age-associated changes in the expression of GluN2C and GluN2D of the NMDA receptor subunit are not observed in the mouse hippocampus or cortex (Magnusson, 2012), and there are few studies performed to detect the influence of aging on expression of GluN3A and GluN3B subunits of the NMDA receptor.

From a physiological point of view, the alterations in the expression of specific GluN2 subunits could have dramatic influences on NMDA receptor function through the regulation of mean channel open time and conductance of the NMDA receptors. Studies on recombinant NMDA receptor expressed in Xenopus oocytes demonstrate that NMDA receptors containing the GluN2A subunit (GluN2A-NMDA receptors) have faster deactivation kinetics and higher open probability relative to GluN2B containing NMDA receptors (GluN2B-NMDA receptors) (Vicini et al., 1998; Cull-Candy et al., 2001; Erreger et al., 2005; Gray et al., 2011), such that smaller ion flux is observed for the GluN2A-NMDA receptors, relative to the GluN2B-NMDA receptors. Thus, a shift in the level of GluN2 subunit expression could modulate the time course and magnitude of the $\mathrm{Ca}^{2+}$ signal leading to reduced $\mathrm{Ca}^{2+}$ influx associated with the loss of GluN2B subunits. A shift in GluN2A and GluN2B expression is thought to contribute to developmental changes in cognition and synaptic function (Dumas, 2005). Overview of literature suggests that an adequate balance between GluN2A and GluN2B might be a key mechanism for the optimal functioning of the NMDA receptor.

\section{Location}

Alternatively, alterations in the NMDA receptor localization, through the insertion of receptors into the membrane or recruitment of extra-synaptic receptors into the synapse, may 
influence NMDA receptor function with advanced aging. Results suggested that GluN2B containing receptors may be more prevalent at extra-synaptic sites (Massey et al., 2004), which could temporarily house the NMDA receptors before being internalized into the cytoplasm (Blanpied et al., 2002; Lau and Zukin, 2007). In the frontal cortex, the expression of the GluN2B subunit is reduced in the synaptic membrane fraction, but not in the whole homogenate of brain tissue from senescent mice suggesting that GluN2B containing receptor sequestration at the extra-synaptic sites may be the mechanism by which the GluN2B levels decline during aging (Zhao et al., 2009). Finally, results indicate that extra-synaptic NMDA receptors couple to different signaling cascades, initiate mechanisms that oppose synaptic potentiation, by shutting off the activity of cAMP response element binding protein and decreasing expression of brain-derived neurotropic factor (Hardingham et al., 2002; Vanhoutte and Bading, 2003). However, it remains to be determined whether alteration in NMDA receptor location, specifically extra-synaptic localization, is a contributing mechanism to NMDA receptor hypofunction during senescence.

\section{Translational Modifications}

An additional probable candidate mechanism for regulating NMDA receptor function during aging is post-translational modification of the receptor. In particular, the function of the NMDA receptor is influenced by its phosphorylation state. Activation of the tyrosine kinase (Wang et al., 1994; Heidinger et al., 2002), protein kinase C (Ben-Ari et al., 1992; Chen and Huang, 1992) and protein kinase A (Raman et al., 1996) increases NMDA receptor mediated currents. In contrast, protein phosphatases, including calcineurin and protein phosphatase 1, decrease NMDA receptor currents (Lieberman and Mody, 1994; Wang et al., 1994; Raman et al., 1996). Phosphorylation state of GluN1, GluN2A, or GluN2B subunits can rapidly regulate surface expression and localization of the NMDA receptors (Gardoni et al., 2001; Chung et al., 2004; Hallett et al., 2006; Lin et al., 2006). For example, phosphorylation of serine residues within the alternatively spliced cassettes of the C-terminal tail of GluN1 promotes receptor trafficking from the endoplasmic reticulum and insertion into the post-synaptic membrane (Scott et al., 2001; Carroll and Zukin, 2002). Finally, increased phosphatase activity has been linked to the internalization of NMDA receptors (Snyder et al., 2005). Thus, the kinases and phosphatases act like molecular switches that increase or decrease NMDA receptor function, respectively. Interestingly, aging is associated with a shift in the balance of kinase/phosphatase activity, favoring an increase in the phosphatase activity (Norris et al., 1998; Foster et al., 2001; Foster, 2007). Thus, age-associated alterations in the phosphorylation state of the NMDA receptor might contribute to the decrease in the NMDA receptor function during aging (Coultrap et al., 2008). Future research is desired to delineate the direct interaction between the age-induced altered kinase/phosphatase activity and NMDA receptor function.

\section{Oxidative Stress}

Age-associated augmented oxidative stress might influence the subunit composition, expression, trafficking, and NMDA receptor function. Oxidation and reduction of sulfhydryl moieties alter NMDA receptor function. Three pairs of cysteine residues located within the $\mathrm{N}$-terminal regulatory domain of the receptor (two pairs reside in GluN1 and one pair resides in GluN2A subunit) are involved in oxidation-reduction (redox) modulation of NMDA receptor (Choi and Lipton, 2000; Choi et al., 2001; Lipton et al., 2002). Previous research demonstrates that oxidizing agents such as 5,5'-dithiobis-(2-nitrobenzoic acid) (Aizenman et al., 1989), hydroxyl radicals generated by xanthine/xanthine oxidase (Aizenman, 1995) and oxidized glutathione (Sucher and Lipton, 1991) decrease NMDA receptor function in the neuronal cell cultures. The decrease in NMDA receptor function under oxidizing conditions is thought to result from the formation of disulfide bonds on the sulfhydryl group-containing amino acid residues in the NMDA receptor (Aizenman et al., 1990; Sullivan et al., 1994; Choi et al., 2001). The aging brain is associated with an increase in oxidative stress and/or a decrease in redox buffering capacity (Foster, 2006; Poon et al., 2006; Parihar et al., 2008), conditions that promote a decrease in NMDA receptor function. Results demonstrate that an age-related decrease in NMDA receptor function is related to oxidative stress and a post-synaptic shift in the intracellular redox environment (Bodhinathan et al., 2010a,b; Robillard et al., 2011; Haxaire et al., 2012; Lee et al., 2014). Our recent results provide evidence for a link between the redox-mediated decline in NMDA receptor function and the emergence of an age-related cognitive phenotype with impairment in the rapid acquisition and retention of novel spatial information (Figure 3; Kumar and Foster, 2013; Lee et al., 2014).

\section{Microglia Interaction}

Local supporting cells, astrocytes and microglia, can regulate NMDA receptor function in neurons and may provide additional possible mechanisms for the age-related changes to NMDA receptor function. Astrocytes are a major source of D-serine, an endogenous co-agonist for the NMDA receptor that binds to the glycine binding site (Schell et al., 1995). An age-related loss of D-serine is observed in the hippocampus and cortex of rats (Williams et al., 2006). Microglia contributes to the brain's immune system and activated microglia can release D-serine (Wu and Barger, 2004; Wu et al., 2004). In accordance with this idea, recent reports suggest that microglia can potentiate the NMDA receptor-mediated synaptic responses in cortical neurons (Moriguchi et al., 2003; Hayashi et al., 2006). Markers of neuroinflammation increase with advancing age and in certain neurodegenerative disorders. Finally, there is evidence for a feedback reduction in NMDA receptors due to excess synaptic glutamate activity during microglial activation (Rosi et al., 2004, 2006).

In light of the interaction of NMDA receptors and microglia, it is imperative to consider the probability that the reduction in NMDA receptor function might represent a compensatory neuroprotective mechanism associated with inappropriate receptor activity or increased $\mathrm{Ca}^{2+}$ due to other mechanisms. Thus, impaired NMDA receptor-dependent synaptic plasticity and memory decline may be epiphenomena due to processes for cell preservation (Foster, 1999). Indeed, 


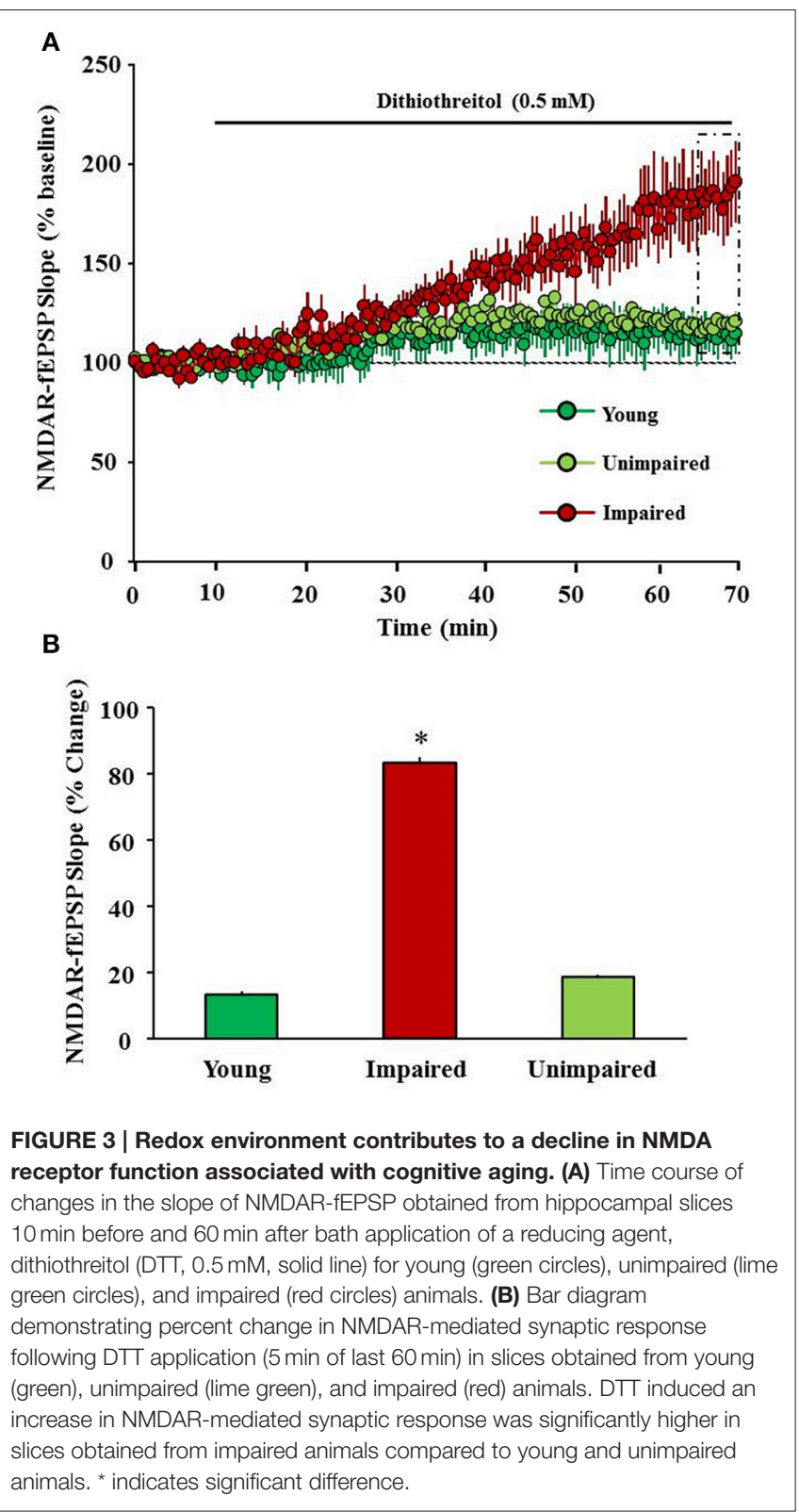

over expression of GluN2B subunits improves synaptic plasticity and memory in aged mice (Cao et al., 2007; Brim et al., 2013) indicating that increased NMDA receptor function can rescue physiological symptoms of cognitive aging. However, cognition and synaptic plasticity are also improved by treating with the low-affinity voltage-dependent NMDA receptor channel blocker, memantine (Barnes et al., 1996; Pietá Dias et al., 2007), possibly by reducing inappropriate NMDA receptor activity (Rosi et al., 2006; Matute, 2007; Chang and Gold, 2008). Memantine, a non-competitive moderate and partial NMDA receptor channel blocker, can attenuate the over activation of the NMDA receptor by preventing influx of excessive $\mathrm{Ca}^{2+}$ without influencing physiological activity of NMDA receptor (Scarpini et al., 2003; Gardoni and Di Luca, 2006; Pallàs and Camins, 2006). In clinical studies, memantine has been demonstrated to have beneficial effects for patients with moderate to severe Alzheimer's disease, while has no effect in mild AD patients (Reisberg et al., 2003). Initial studies described positive effects of memnatine on cognition in demented patients (Ditzler, 1991), neuronal plasticity and learning in senescent animals (Barnes et al., 1996), water maze performance in adult male rats (Zoladz et al., 2006), and spatial learning in transgenic mice (Minkeviciene et al., 2004). However, results for the efficacy of memantine's beneficial influence on cognition are controversial. Memantine reduces agitation and delusions in severe $\mathrm{AD}$ cases and yet has little or no cognitive benefit for mild $\mathrm{AD}$, including impaired executive function (Reisberg et al., 2003; Parsons et al., 2007; Schneider et al., 2011; Huang et al., 2012). Furthermore, a recent study demonstrated that memantine fail to improve significant agitation in people with moderate to severe $\mathrm{AD}$ (Fox et al., 2012). Future studies are required to clearly examine the efficacy of memantine for cognitive benefits and other neuropsychiatric symptoms.

\section{NMDA RECEPTOR HYPOFUNCTION AND ITS INFLUENCE ON COGNITIVE PERFORMANCE}

NMDA receptors play an important role in learning and memory, and are critical for spatial memory (Morris et al., 1986; Collingridge, 1987; Mondadori et al., 1989; Morris, 1989; Mondadori and Weiskrantz, 1993; Lisman et al., 1998; Martin et al., 2000; Foster, 2012; Guidi et al., 2015b); NMDA receptormediated synaptic plasticity and its hypofunction is thought to play a vital role in age-associated cognitive impairments (Foster and Norris, 1997; Foster, 2012; Kumar and Foster, 2013). Advanced age is associated with a decrease in subunit expression and a decline in NMDA receptor function. Mounting evidence suggests that an age-associated deficiency in NMDA receptor contributes to impairment in spatial learning and memory (Davis et al., 1993; Magnusson, 1998b, 2001; Clayton et al., 2002b; Magnusson et al., 2007; Das and Magnusson, 2008, 2011; Zhao et al., 2009; Das et al., 2012; Foster, 2012; Zamzow et al., 2013). The age-associated decrease in the GluN2B subunit of the NMDA receptor contributes to some forms of memory decline during senescence (Zamzow et al., 2013). Prior work regarding the NMDA receptor and its functional state during aging has been largely focused on the hippocampus (Barnes et al., 1997; Magnusson, 1998a; Eckles-Smith et al., 2000; Zhao et al., 2009; Kumar and Foster, 2013). Our results also provide evidence by showing blunted NMDA receptor mediated synaptic potentials in memory impaired animals when compared with unimpaired animals (Figure 2B; Kumar and Foster, 2013). These results demonstrate that NMDA receptor-mediated synaptic responses at CA3-CA1 hippocampal synapses are significantly decreased with advanced age. Examination of synaptic transmission, according to behavioral classification, revealed that animals classified as impaired exhibited a decrease in the NMDA receptor component of the synaptic response relative to young and unimpaired animals. Recent results successfully demonstrate that viral vector mediated upregulation of the GluN2B subunit 
of NMDA receptor in aged animals enhances hippocampaldependent memory and synaptic transmission (Brim et al., 2013). Furthermore, we provide evidence for a link between the redoxmediated decline in NMDA receptor function and the emergence of age-related memory impairment (Kumar and Foster, 2013). These results demonstrate that bath application of the reducing agent dithiothreitol enhanced the NMDA receptor component of the synaptic response to a greater extent in impaired animals relative to unimpaired and young rats (Figure 3 ).

In addition to the hippocampus, there are studies that indicate an age-associated decrease in NMDA receptor-mediated synaptic plasticity in other brain regions that might contribute to impairments in cognitive function (Bourne and Harris, 2007; Morrison and Baxter, 2012). Our most recent results demonstrate a robust decrease in NMDA receptor mediated synaptic responses in the medial prefrontal cortex, and the decrease in NMDA receptor function was due in part to an altered redox state, which was associated with several measures of prefrontal cortex-dependent behavior (Guidi et al., 2015a). These results indicate that redox mediated changes contribute to altered NMDA receptor function and provide possible mechanisms that may underlie impairment in cognitive performance associated with advanced age. However, a clear understanding, in regards to how alterations in NMDA receptor function associated with either advanced age or with neurodegenerative diseases that contribute to cognitive impairment, is essential.

\section{RESTORING NMDA RECEPTOR FUNCTION WITH ADVANCED AGE}

One simple notion is that augmenting the NMDA receptor subunit expression and function should ameliorate cognitive function. The challenge is how to restore or prevent the diminishing NMDA receptor function over the course of a life span and in neurodegenerative diseases. Pharmacological agents such as $\mathrm{N}$-acetylcysteine (NAC) and D-cycloserine have provided an avenue to enhance NMDA receptor function and reverse negative consequences associated with NMDA receptor hypofunction. NAC is a derivative of the amino acid Lcysteine with an added acetyl group attached to the nitrogen atom, which serves as a precursor for the formation of the antioxidant glutathione ( $\gamma$-glutamylcysteinylglycine; GSH) in the body (Ziment, 1988). The tripeptide GSH is a potent endogenous antioxidant produced by cells and is important for the maintenance of redox potential in the brain (Reid and Jahoor, 2001; Cruz et al., 2003). The thiol (sulfhydryl) group confers the antioxidant properties. Previous research examining the ability of reducing and oxidizing (redox) agents to modulate NMDA receptor activity in cell cultures and in tissue from neonates suggests that redox state is an imperative determinant of NMDA receptor function possibly through oxidation of extracellular cysteine residues on the NMDA receptor subunits; NMDA receptors are redox sensitive protein that requires a healthy redox balance (Aizenman et al., 1989, 1990; Tang and Aizenman, 1993; Bernard et al., 1997; Choi and Lipton, 2000; Lipton et al., 2002). The redox sensitive intracellular molecules affect NMDA receptor function and the aged brain exhibits augmented oxidative damage and a decrease in redox buffering capacity (Foster, 2006; Poon et al., 2006; Parihar et al., 2008). Our published results demonstrate that age-associated enhanced oxidative stress contributes to NMDA receptor hypofunction, and the reducing agent significantly improved the NMDA receptor mediated synaptic response (Bodhinathan et al., 2010a; Kumar and Foster, 2013; Lee et al., 2014; Guidi et al., 2015a; Figure 3). NAC, being an antioxidant and anti-inflammatory agent, has the abilities to modulate NMDA receptor activity. Long-term dietary treatment with NAC is beneficial in alleviating age-associated neuronal alterations induced by an impaired antioxidant defense system (Martínez et al., 2000; Cocco et al., 2005). Results from a recent study eloquently demonstrated that long-term dietary supplementation with NAC prevented age-induced oxidative damage in the hippocampus and restored NMDA receptor-mediated long-term potentiation at CA3-CA1 hippocampal synapses. Additionally, the authors demonstrated that age-associated decrease in levels of D-serine, a NMDA receptor co-agonist that is required for receptor activation, and expression of serine racemase, an enzyme that is responsible for synthesis of D-serine from $\mathrm{L}$ serine, are rescued by long-term dietary treatment with NAC (Haxaire et al., 2012). NAC, being a precursor of GSH, can protect the brain from low levels of GSH and improve cognitive performance (Fu et al., 2006; Robillard et al., 2011). Results also demonstrate that long-term dietary supplementation with NAC can restore age-induced impaired hippocampal synaptic plasticity close to that of the adult level (Robillard et al., 2011). An enhancement in NMDA receptor current has also been observed following acute application of NAC in cortical neurons (Dukoff et al., 2014). Review of the literature provides abundant evidence for beneficial influence of NAC on antioxidant balance, neurotransmission, neurogenesis, and inflammation. Adjunctive supplementations with NAC improve the symptoms of bipolar disorder, Alzheimer's disease, depression, cognitive impairment, and other psychiatric disorders (Butterfield and Pocernich, 2003; Jayalakshmi et al., 2007; Lanté et al., 2008; Choy et al., 2010; Goncalves et al., 2010; Jain et al., 2011; Otte et al., 2011; Dean et al., 2012; Dhanda et al., 2013; Rodrigues et al., 2013; Carvalho et al., 2014; Steullet et al., 2014; Thakurta et al., 2014; Soleimani Asl et al., 2015). For more details about therapeutic potential of NAC in ameliorating various pathological conditions, readers are referred to excellent review articles published previously (Kelly, 1998; Dean et al., 2012). Future studies are needed to explore the beneficial influence of NAC on NMDA receptor hypofunction and its consequence on cognitive impairments in hippocampal dependent spatial memory and prefrontal cortexdependent executive function associated with senescence and other pathological disorders.

Another pharmacological agent, D-cycloserine ((4R)-4amino-1,2-oxazolidin-3-one, DCS), a partial agonist and positive modulator of the NMDA receptor, binds at strychnine-sensitive glycine modulatory site of the receptor and enhances NMDA receptor function (Johnson and Ascher, 1987; Reynolds et al., 1987; Hood et al., 1989; Kemp and Leeson, 1993). DCS acts as an antagonist by shifting more efficient endogenous agonists like 
D-serine at high dose. A low dose of DCS can act as an agonist and facilitate NMDA receptor function (Horio et al., 2013). There are numerous reports suggesting the beneficial influence of DCS on cognitive performance and other neurodegenerative diseases (Thompson et al., 1992; Baxter et al., 1994; Ohno and Watanabe, 1996; Gabriele and Packard, 2007; Yaka et al., 2007; Curlik and Shors, 2011; Kuriyama et al., 2011; Feld et al., 2013; Kranjac et al., 2013; Ren et al., 2013). Peripheral injection of DCS, which crosses the blood-brain barrier, has been shown to enhance learning rate and rescue impaired memory consolidation (Thompson et al., 1992; Kranjac et al., 2013). DCS can modulate NMDA receptor-mediated neurotransmission and has the potential to restore impaired NMDA receptor function associated with aging or pathological condition. Results indicate that age-associated impaired cognition is improved by DCS treatment (Baxter et al., 1994; Aura and Riekkinen, 2000). In young animals, DCS enhanced NMDA receptor activation and facilitated hippocampal neurotransmission (Pitkänen et al., 1994; Rouaud and Billard, 2003; Donzis and Thompson, 2014). Furthermore, a senescence-induced deficit in NMDA receptor mediated neurotransmission is restored by DCS (Billard and Rouaud, 2007). A study by Kochlamazashvili and colleagues demonstrated that DCS restored learning in the fear conditioning paradigm and improved long-term NMDA-mediated synaptic transmission in aged neural cell adhesion molecule deficient animals by upregulating the GluN2A subunit of the NMDA receptor (Kochlamazashvili et al., 2012). Readers interested in details regarding to DCS influences on cognitive performance and neurotransmission over the life span and in neuropathological conditions may consult previously published review articles (Norberg et al., 2008; Huang et al., 2012; Lin et al., 2014; Hofmann et al., 2015).

Future studies are needed in order to delineate the influence of DCS on specific NMDA receptor subunit configurations and its functional outcome in regards to ameliorating age-associated impaired cognition and NMDA receptor hypofunction over the life span.

$\mathrm{D}$-serine is a potent endogenous ligand that binds at the glycine binding site of the NMDA receptor and acts as a neuronal signaling molecule leading to upregulation of NMDA receptors. In addition, it is released from astrocytes and is highly expressed in the brain (Schell et al., 1995; Mothet et al., 2000; De Miranda et al., 2002; Nishikawa, 2005; Fossat et al., 2012). $\mathrm{D}$-serine is required for NMDA receptor activation, and may have preferential affinity/effectiveness for NMDA receptors that contain GluN2B subunits (Priestley et al., 1995). The levels of Dserine are dramatically reduced with advanced age (Junjaud et al., 2006; Mothet et al., 2006; Turpin et al., 2011). One possibility is a loss of the serine racemase enzyme, which generates Dserine from L-serine (Wolosker et al., 1999a,b). A decline in serine racemase mRNA is observed in the prefrontal cortex of aging humans (Loerch et al., 2008) and the hippocampus of aged rats (Turpin et al., 2011). The enzyme serine racemase generates D-serine from L-serine; pharmacological or viral gene delivery tools could be employed to increase endogenous levels of $\mathrm{D}$-serine or serine racemase expression. Currently, there is some debate as to the source of serine racemase, either neuronal or glial (Wolosker et al., 1999a; Wolosker, 2011; Wolosker and Mori, 2012); however, recent results provide convincing evidence that serine racemase is primarily expressed by neurons (Yoshikawa et al., 2007; Miya et al., 2008; Rosenberg et al., 2010; Ding et al., 2011). There are reports that oral treatment or intracerebroventricular infusion of DCS induced a marked increase in extracellular D-serine levels within the hippocampus of SRR-knockout mice (Horio et al., 2013). Future studies to upregulate the expression of serine racemase, in order to enhance the endogenous level of D-serine, could provide another avenue to restore impaired NMDA receptor function during aging and under pathological conditions.

Recent studies, employing genetic tools, provide another alternative to enhance NMDA receptor function. A great advantage of this technology is that we can study the effect of single genes, or gene combinations by injecting mixtures of viral vectors to upregulate expression of target genes. Dose response studies, by injecting dilutions of viral vector, to analyze the effects of different levels of expression/transduction of the GluN1/GluN2A/B subunits, can also be performed along with functional significance of enhanced expression of the receptor. Viral vectors were originally developed as an alternative to transfection of genetic material (DNA) into cells. Now the viral vector-mediated gene delivery technique is more commonly used to upregulate or downregulate a target gene into living cells. This tool provides an excellent opportunity to overexpress various subunits of the NMDA receptor and measure its functional consequence on behavioral performance. Our results clearly illustrate rescuing age-associated impaired hippocampal-dependent spatial memory by enhanced expression of the GluN2B subunit of the NMDA receptor (Brim et al., 2013). More research in this direction will be essential to explore the impact of augmenting expression of various NMDA receptor subunits alone or in combinations on NMDA receptor function including synaptic transmission and cognitive performance. In addition to analyzing beneficial influence of augmented NMDA receptor subunit expression/function, future research should also investigate possible side effects and other stipulations associated with enhanced function of NMDA receptor.

\section{CONCLUSION AND OUTLOOK}

Now there is mounting evidence, which suggest that the subunit expression, configuration, and function of the NMDA receptor are altered with advancing age. Vista of factors including subunit expression, topography, oxidative stress, interaction with scaffolding proteins and glial cells, receptor trafficking, and translation, tempered by aging might be contributing to NMDA receptor hypofunction. Due to the critical importance of NMDA receptors in synaptic transmission and memory, a selective upregulation of NMDA receptor subunits in neurons may provide an avenue for treating ageassociated cognitive deficits. Clearly, future research will need to delineate the contributions of several mechanisms in optimizing specific subunit contribution and influence of upregulation in 
mediating learning and memory function. Thus, it will be imperative for future research to determine whether enhancing or inhibiting NMDA receptor function by upregulating or downregulating different subunits expression configurations will be beneficial in preserving cognitive domain during normal senescence.

\section{REFERENCES}

Adams, M. M., Morrison, J. H., and Gore, A. C. (2001). N-methyl-Daspartate receptor mRNA levels change during reproductive senescence in the hippocampus of female rats. Exp. Neurol. 170, 171-179. doi: 10.1006/exnr.2001.7687

Aizenman, E. (1995). Modulation of N-methyl-D-aspartate receptors by hydroxyl radicals in rat cortical neurons in vitro. Neurosci. Lett. 189, 57-59. doi: 10.1016/0304-3940(95)11442-Y

Aizenman, E., Hartnett, K. A., and Reynolds, I. J. (1990). Oxygen free radicals regulate NMDA receptor function via a redox modulatory site. Neuron 5, 841-846. doi: 10.1016/0896-6273(90)90343-E

Aizenman, E., Lipton, S. A., and Loring, R. H. (1989). Selective modulation of NMDA responses by reduction and oxidation. Neuron 2, 1257-1263. doi: 10.1016/0896-6273(89)90310-3

Al-Hallaq, R. A., Jarabek, B. R., Fu, Z., Vicini, S., Wolfe, B. B., and Yasuda, R. P. (2002). Association of NR3A with the N-methyl-D-aspartate receptor NR1 and NR2 subunits. Mol. Pharmacol. 62, 1119-1127. doi: 10.1124/mol.62.5.1119

Araki, T., Kato, H., Nagaki, S., Shuto, K., Fujiwara, T., and Itoyama, Y. (1997). Effects of vinconate on age-related alterations in $[3 \mathrm{H}] \mathrm{MK}-801,[3 \mathrm{H}]$ glycine, sodium-dependent D-[3H] aspartate, [3H]FK-506 and [3H]PN200-110 binding in rats. Mech. Ageing Dev. 95, 13-29. doi: 10.1016/S0047-6374(96)01831-3

Aura, J., and Riekkinen, P. Jr. (2000). Pre-training blocks the improving effect of tetrahydroaminoacridine and D-cycloserine on spatial navigation performance in aged rats. Eur. J. Pharmacol. 390, 313-318. doi: 10.1016/S00142999(00)00054-6

Bai, L., Hof, P. R., Standaert, D. G., Xing, Y., Nelson, S. E., Young, A. B., et al. (2004). Changes in the expression of the NR2B subunit during aging in macaque monkeys. Neurobiol. Aging 25, 201-208. doi: 10.1016/S01974580(03)00091-5

Barnes, C. A., Danysz, W., and Parsons, C. G. (1996). Effects of the uncompetitive NMDA receptor antagonist memantine on hippocampal longterm potentiation, short-term exploratory modulation and spatial memory in awake, freely moving rats. Eur. J. Neurosci. 8, 565-571. doi: 10.1111/j.14609568.1996.tb01241.x

Barnes, C. A., Rao, G., and Shen, J. (1997). Age-related decrease in the N-methylD-aspartateR-mediated excitatory postsynaptic potential in hippocampal region CA1. Neurobiol. Aging 18, 445-452. doi: 10.1016/S0197-4580(97) 00044-4

Baxter, M. G., Lanthorn, T. H., Frick, K. M., Golski, S., Wan, R. Q., and Olton, D. S. (1994). D-cycloserine, a novel cognitive enhancer, improves spatial memory in aged rats. Neurobiol. Aging 15, 207-213. doi: 10.1016/0197-4580(94)90114-7

Ben-Ari, Y., Aniksztejn, L., and Bregestovski, P. (1992). Protein kinase C modulation of NMDA currents: an important link for LTP induction. Trends Neurosci. 15, 333-339. doi: 10.1016/0166-2236(92)90049-E

Bernard, C. L., Hirsch, J. C., Khazipov, R., Ben-Ari, Y., and Gozlan, H. (1997). Redox modulation of synaptic responses and plasticity in rat CA1 hippocampal neurons. Exp. Brain Res. 113, 343-352. doi: 10.1007/BF02450332

Billard, J. M., and Rouaud, E. (2007). Deficit of NMDA receptor activation in CA1 hippocampal area of aged rats is rescued by D-cycloserine. Eur. J. Neurosci. 25, 2260-2268. doi: 10.1111/j.1460-9568.2007.05488.x

Blanpied, T. A., Scott, D. B., and Ehlers, M. D. (2002). Dynamics and regulation of clathrin coats at specialized endocytic zones of dendrites and spines. Neuron 36, 435-449. doi: 10.1016/S0896-6273(02)00979-0

Bodhinathan, K., Kumar, A., and Foster, T. C. (2010a). Intracellular redox state alters NMDA receptor response during aging through

\section{ACKNOWLEDGMENTS}

Financial support by National Institutes of Health Grants, AG037984, AG036800, AG049711, NS040389, and the Evelyn F. McKnight Brain Research Grant is highly appreciated. Special thanks to Dr. Linda Bean for editorial reading.

$\mathrm{Ca}^{2+} /$ calmodulin-dependent protein kinase II. J. Neurosci. 30, 1914-1924. doi: 10.1523/JNEUROSCI.5485-09.2010

Bodhinathan, K., Kumar, A., and Foster, T. C. (2010b). Redox sensitive calcium stores underlie enhanced after hyperpolarization of aged neurons: role for ryanodine receptor mediated calcium signaling. J. Neurophysiol. 104, 2586-2593. doi: 10.1152/jn.00577.2010

Bonhaus, D. W., Perry, W. B., and McNamara, J. O. (1990). Decreased density, but not number, of $\mathrm{N}$-methyl-D-aspartate, glycine and phencyclidine binding sites in hippocampus of senescent rats. Brain Res. 532, 82-86. doi: 10.1016/00068993(90)91745-3

Bourne, J., and Harris, K. M. (2007). Do thin spines learn to be mushroom spines that remember? Curr. Opin. Neurobiol. 17, 381-386. doi: 10.1016/j.conb.2007.04.009

Brim, B. L., Haskell, R., Awedikian, R., Ellinwood, N. M., Jin, L., Kumar, A., et al. (2013). Memory in aged mice is rescued by enhanced expression of the GluN2B subunit of the NMDA receptor. Behav. Brain Res. 238, 211-226. doi: 10.1016/j.bbr.2012.10.026

Burnashev, N., and Szepetowski, P. (2015). NMDA receptor subunit mutations in neurodevelopmental disorders. Curr. Opin. Pharmacol. 20C, 73-82. doi: 10.1016/j.coph.2014.11.008

Butterfield, D. A., and Pocernich, C. B. (2003). The glutamatergic system and Alzheimer's disease: therapeutic implications. CNS Drugs 17, 641-652. doi: 10.2165/00023210-200317090-00004

Cao, X., Cui, Z., Feng, R., Tang, Y. P., Qin, Z., Mei, B., et al. (2007). Maintenance of superior learning and memory function in NR2B transgenic mice during ageing. Eur. J. Neurosci. 25, 1815-1822. doi: 10.1111/j.1460-9568.2007.05431.x

Carroll, R. C., and Zukin, R. S. (2002). NMDA-receptor trafficking and targeting: implications for synaptic transmission and plasticity. Trends Neurosci. 25, 571-577. doi: 10.1016/S0166-2236(02)02272-5

Carvalho, A. F., Miskowiak, K. K., Hyphantis, T. N., Kohler, C. A., Alves, G. S., Bortolato, B., et al. (2014). Cognitive dysfunction in depression, pathophysiology and novel targets. CNS Neurol. Disord. Drug Targets 13, 1819-1835. doi: 10.2174/1871527313666141130203627

Chang, Q., and Gold, P. E. (2008). Age-related changes in memory and in acetylcholine functions in the hippocampus in the Ts65Dn mouse, a model of Down syndrome. Neurobiol. Learn. Mem. 89, 167-177. doi: 10.1016/j.nlm.2007.05.007

Chen, L., and Huang, L. Y. (1992). Protein kinase C reduces $\mathrm{Mg}^{2+}$ block of NMDAreceptor channels as a mechanism of modulation. Nature 356, 521-523. doi: $10.1038 / 356521 \mathrm{a} 0$

Chen, N., Luo, T., and Raymond, L. A. (1999). Subtype-dependence of NMDA receptor channel open probability. J. Neurosci. 19, 6844-6854.

Chen, P. E., Geballe, M. T., Stansfeld, P. J., Johnston, A. R., Yuan, H., Jacob, A. L., et al. (2005). Structural features of the glutamate binding site in recombinant NR1/NR2A N-methyl-D-aspartate receptors determined by sitedirected mutagenesis and molecular modeling. Mol. Pharmacol. 67, 1470-1484. doi: 10.1124/mol.104.008185

Choi, Y., Chen, H. V., and Lipton, S. A. (2001). Three pairs of cysteine residues mediate both redox and $\mathrm{zn}^{2+}$ modulation of the nmda receptor. J. Neurosci. 21, 392-400.

Choi, Y. B., and Lipton, S. A. (2000). Redox modulation of the NMDA receptor. Cell. Mol. Life Sci. 57, 1535-1541. doi: 10.1007/PL00000638

Choy, K. H., Dean, O., Berk, M., Bush, A. I., and van den Buuse, M. (2010). Effects of $\mathrm{N}$-acetyl-cysteine treatment on glutathione depletion and a short-term spatial memory deficit in 2-cyclohexene-1-one-treated rats. Eur. J. Pharmacol. 649, 224-228. doi: 10.1016/j.ejphar.2010.09.035 
Chung, H. J., Huang, Y. H., Lau, L. F., and Huganir, R. L. (2004). Regulation of the NMDA receptor complex and trafficking by activitydependent phosphorylation of the NR2B subunit PDZ ligand. J. Neurosci. 24, 10248-10259. doi: 10.1523/JNEUROSCI.0546-04.2004

Clayton, D. A., and Browning, M. D. (2001). Deficits in the expression of the NR2B subunit in the hippocampus of aged Fisher 344 rats. Neurobiol. Aging 22, 165-168. doi: 10.1016/S0197-4580(00)00196-2

Clayton, D. A., Grosshans, D. R., and Browning, M. D. (2002a). Aging and surface expression of hippocampal NMDA receptors. J. Biol. Chem. 277, 14367-14369. doi: 10.1074/jbc.C200074200

Clayton, D. A., Mesches, M. H., Alvarez, E., Bickford, P. C., and Browning, M. D. (2002b). A hippocampal NR2B deficit can mimic age-related changes in longterm potentiation and spatial learning in the Fischer 344 rat. J. Neurosci. 22, 3628-3637.

Cocco, T., Sgobbo, P., Clemente, M., Lopriore, B., Grattagliano, I., Di Paola, M., et al. (2005). Tissue-specific changes of mitochondrial functions in aged rats: effect of a long-term dietary treatment with $\mathrm{N}$-acetylcysteine. Free Radic. Biol. Med. 38, 796-805. doi: 10.1016/j.freeradbiomed.2004. 11.034

Collingridge, G. (1987). Synaptic plasticity. The role of NMDA receptors in learning and memory. Nature 330, 604-605. doi: 10.1038/330604a0

Collingridge, G. L., Olsen, R. W., Peters, J., and Spedding, M. (2009). A nomenclature for ligand-gated ion channels. Neuropharmacology 56, 2-5. doi: 10.1016/j.neuropharm.2008.06.063

Cotman, C., and Monaghan, D. (1989). Multiple excitatory amino acid receptor regulation of intracellular $\mathrm{Ca}^{2+}$. Implications for aging and Alzheimer's disease. Ann. N.Y. Acad. Sci. 568, 138-148. doi: 10.1111/j.1749-6632.1989. tb12501.x

Cotman, C. W., Geddes, J. W., Bridges, R. J., and Monaghan, D. T. (1989). Nmethyl-D-aspartate receptors and Alzheimer's disease. Neurobiol. Aging 10, 603-605. discussion: 618-620. doi: 10.1016/0197-4580(89)90144-9

Coultrap, S. J., Bickford, P. C., and Browning, M. D. (2008). Blueberry-enriched diet ameliorates age-related declines in NMDA receptor-dependent LTP. Age 30, 263-272. doi: 10.1007/s11357-0089067-y

Cruz, R., Almaguer Melian, W., and Bergado Rosado, J. A. (2003). Glutathione in cognitive function and neurodegeneration. Rev. Neurol. 36, 877-886.

Cull-Candy, S., Brickley, S., and Farrant, M. (2001). NMDA receptor subunits: diversity, development and disease. Curr. Opin. Neurobiol. 11, 327-335. doi: 10.1016/S0959-4388(00)00215-4

Curlik, D. M. II, and Shors, T. J. (2011). Learning increases the survival of newborn neurons provided that learning is difficult to achieve and successful. J. Cogn. Neurosci. 23, 2159-2170. doi: 10.1162/jocn.2010.21597

Das, S. R., Jensen, R., Kelsay, R., Shumaker, M., Bochart, R., Brim, B., et al. (2012). Reducing expression of GluN1(0XX) subunit splice variants of the NMDA receptor interferes with spatial reference memory. Behav. Brain Res. 230, 317-324. doi: 10.1016/j.bbr.2012.02.014

Das, S. R., and Magnusson, K. R. (2008). Relationship between mRNA expression of splice forms of the zetal subunit of the N-methyl-D-aspartate receptor and spatial memory in aged mice. Brain Res. 1207, 142-154. doi: 10.1016/j.brainres.2008.02.046

Das, S. R., and Magnusson, K. R. (2011). Changes in expression of splice cassettes of NMDA receptor GluN1 subunits within the frontal lobe and memory in mice during aging. Behav. Brain Res. 222, 122-133. doi: 10.1016/j.bbr.2011. 03.045

Davis, S., Markowska, A. L., Wenk, G. L., and Barnes, C. A. (1993). Acetyl-L-carnitine: behavioral, electrophysiological, and neurochemical effects. Neurobiol. Aging 14, 107-115. doi: 10.1016/0197-4580(93)90030-F

Dean, O. M., Bush, A. I., Copolov, D. L., Kohlmann, K., Jeavons, S., Schapkaitz, I., et al. (2012). Effects of $\mathrm{N}$-acetyl cysteine on cognitive function in bipolar disorder. Psychiatry Clin. Neurosci. 66, 514-517. doi: 10.1111/j.14401819.2012.02392.x

De Miranda, J., Panizzutti, R., Foltyn, V. N., and Wolosker, H. (2002). Cofactors of serine racemase that physiologically stimulate the synthesis of the N-methylD-aspartate (NMDA) receptor coagonist D-serine. Proc. Natl. Acad. Sci. U.S.A. 99, 14542-14547. doi: 10.1073/pnas.222421299

Dhanda, S., Kaur, S., and Sandhir, R. (2013). Preventive effect of Nacetyl-L-cysteine on oxidative stress and cognitive impairment in hepatic encephalopathy following bile duct ligation. Free Radic. Biol. Med. 56, 204-215. doi: 10.1016/j.freeradbiomed.2012.09.017

Ding, X., Ma, N., Nagahama, M., Yamada, K., and Semba, R. (2011). Localization of D-serine and serine racemase in neurons and neuroglias in mouse brain. Neurol. Sci. 32, 263-267. doi: 10.1007/s10072-010$0422-2$

Dingledine, R., Borges, K., Bowie, D., and Traynelis, S. F. (1999). The glutamate receptor ion channels. Pharmacol. Rev. 51, 7-61.

Ditzler, K. (1991). Efficacy and tolerability of memantine in patients with dementia syndrome. A double-blind, placebo controlled trial. Arzneimittelforschung 41, 773-780.

Donzis, E. J., and Thompson, L. T. (2014). D-cycloserine enhances both intrinsic excitability of CA1 hippocampal neurons and expression of activity-regulated cytoskeletal (Arc) protein. Neurosci. Lett. 571, 50-54. doi: 10.1016/j.neulet.2014.04.035

Dukoff, D. J., Hogg, D. W., Hawrysh, P. J., and Buck, L. T. (2014). Scavenging ROS dramatically increase NMDA receptor whole-cell currents in painted turtle cortical neurons. J. Exp. Biol. 217, 3346-3355. doi: 10.1242/jeb. 105825

Dumas, T. C. (2005). Developmental regulation of cognitive abilities: modified composition of a molecular switch turns on associative learning. Prog. Neurobiol. 76, 189-211. doi: 10.1016/j.pneurobio.2005. 08.002

Eckles-Smith, K., Clayton, D., Bickford, P., and Browning, M. D. (2000). Caloric restriction prevents age-related deficits in LTP and in NMDA receptor expression. Brain research. Mol. Brain Res. 78, 154-162. doi: 10.1016/S0169328X(00)00088-7

Erreger, K., Dravid, S. M., Banke, T. G., Wyllie, D. J., and Traynelis, S. F. (2005). Subunit-specific gating controls rat NR1/NR2A and NR1/NR2B NMDA channel kinetics and synaptic signalling profiles. J. Physiol. 563, 345-358. doi: 10.1113/jphysiol.2004.080028

Erreger, K., and Traynelis, S. F. (2005). Allosteric interaction between zinc and glutamate binding domains on NR2A causes desensitization of NMDA receptors. J. Physiol. 569, 381-393. doi: 10.1113/jphysiol.2005. 095497

Feld, G. B., Lange, T., Gais, S., and Born, J. (2013). Sleep-dependent declarative memory consolidation-unaffected after blocking NMDA or AMPA receptors but enhanced by NMDA coagonist D-cycloserine. Neuropsychopharmacology 38, 2688-2697. doi: 10.1038/npp.2013.179

Flores-Soto, M. E., Chaparro-Huerta, V., Escoto-Delgadillo, M., UreñaGuerrero, M. E., Camins, A., and Beas-Zarate, C. (2013). Receptor to glutamate NMDA-type: the functional diversity of the $\mathrm{nrl}$ isoforms and pharmacological properties. Curr. Pharm. Des. 19, 6709-6719. doi: $10.2174 / 1381612811319380003$

Fossat, P., Turpin, F. R., Sacchi, S., Dulong, J., Shi, T., Rivet, J. M., et al. (2012). Glial D-serine gates NMDA receptors at excitatory synapses in prefrontal cortex. Cereb. Cortex 22, 595-606. doi: 10.1093/cercor/bhr130

Foster, T. C. (1999). Involvement of hippocampal synaptic plasticity in agerelated memory decline. Brain Res. Rev. 30, 236-249. doi: 10.1016/S01650173(99)00017-X

Foster, T. C. (2006). Biological markers of age-related memory deficits: treatment of senescent physiology. CNS Drugs 20, 153-166. doi: 10.2165/00023210200620020-00006

Foster, T. C. (2007). Calcium homeostasis and modulation of synaptic plasticity in the aged brain. Aging Cell 6, 319-325. doi: 10.1111/j.1474-9726.2007. 00283.x

Foster, T. C. (2012). Dissecting the age-related decline on spatial learning and memory tasks in rodent models: $\mathrm{N}$-methyl-D-aspartate receptors and voltagedependent $\mathrm{Ca}^{(2)(+)}$ channels in senescent synaptic plasticity. Prog. Neurobiol. 96, 283-303. doi: 10.1016/j.pneurobio.2012.01.007

Foster, T. C., and Norris, C. M. (1997). Age-associated changes in $\mathrm{Ca}^{2+}$. dependent processes: relation to hippocampal synaptic plasticity. Hippocampus $7,602-612$.

Foster, T. C., Sharrow, K. M., Masse, J. R., Norris, C. M., and Kumar, A. (2001). Calcineurin links $\mathrm{Ca}^{2+}$ dysregulation with brain aging. J. Neurosci. 21, 4066-4073.

Fox, C., Crugel, M., Maidment, I., Auestad, B. H., Coulton, S., Treloar, A., et al. (2012). Efficacy of memantine for agitation in Alzheimer's dementia: a 
randomised double-blind placebo controlled trial. PLoS ONE 7:e35185. doi: 10.1371/journal.pone.0035185

Fu, A. L., Dong, Z. H., and Sun, M. J. (2006). Protective effect of Nacetyl-L-cysteine on amyloid beta-peptide-induced learning and memory deficits in mice. Brain Res. 1109, 201-206. doi: 10.1016/j.brainres.2006. 06.042

Gabriele, A., and Packard, M. G. (2007). D-Cycloserine enhances memory consolidation of hippocampus-dependent latent extinction. Learn. Mem. 14, 468-471. doi: 10.1101/lm.528007

Garaschuk, O., Schneggenburger, R., Schirra, C., Tempia, F., and Konnerth, A. (1996). Fractional $\mathrm{Ca}^{2+}$ currents through somatic and dendritic glutamate receptor channels of rat hippocampal CA1 pyramidal neurones. J. Physiol. 491(Pt 3), 757-772. doi: 10.1113/jphysiol.1996.sp021255

Gardoni, F., and Di Luca, M. (2006). New targets for pharmacological intervention in the glutamatergic synapse. Eur. J. Pharmacol. 545, 2-10. doi: 10.1016/j.ejphar.2006.06.022

Gardoni, F., Schrama, L. H., Kamal, A., Gispen, W. H., Cattabeni, F., and Di Luca, M. (2001). Hippocampal synaptic plasticity involves competition between $\mathrm{Ca}^{2+} /$ calmodulin-dependent protein kinase II and postsynaptic density 95 for binding to the NR2A subunit of the NMDA receptor. J. Neurosci. 21, 1501-1509.

Gazzaley, A. H., Weiland, N. G., McEwen, B. S., and Morrison, J. H. (1996). Differential regulation of NMDAR1 mRNA and protein by estradiol in the rat hippocampus. J. Neurosci. 16, 6830-6838.

Glasgow, N. G., Siegler Retchless, B., and Johnson, J. W. (2015). Molecular bases of NMDA receptor subtype-dependent properties. J. Physiol. 593, 83-95. doi: 10.1113/jphysiol.2014.273763

Goncalves, J. F., Fiorenza, A. M., Spanevello, R. M., Mazzanti, C. M., Bochi, G. V., Antes, F. G., et al. (2010). N-acetylcysteine prevents memory deficits, the decrease in acetylcholinesterase activity and oxidative stress in rats exposed to cadmium. Chem. Biol. Interact. 186, 53-60. doi: 10.1016/j.cbi.2010.04.011

Gonzales, R. A., Brown, L. M., Jones, T. W., Trent, R. D., Westbrook, S. L., and Leslie, S. W. (1991). N-methyl-D-aspartate mediated responses decrease with age in Fischer 344 rat brain. Neurobiol. Aging 12, 219-225. doi: 10.1016/01974580(91) $90100-\mathrm{X}$

Gore, A. C., Oung, T., and Woller, M. J. (2002). Age-related changes in hypothalamic gonadotropin-releasing hormone and N-methyl-D-aspartate receptor gene expression, and their regulation by oestrogen, in the female rat. J. Neuroendocrinol. 14, 300-309. doi: 10.1046/j.1365-2826.2002. 00777.x

Gray, J. A., Shi, Y., Usui, H., During, M. J., Sakimura, K., and Nicoll, R. A. (2011). Distinct modes of AMPA receptor suppression at developing synapses by GluN2A and GluN2B: single-cell NMDA receptor subunit deletion in vivo. Neuron 71, 1085-1101. doi: 10.1016/j.neuron.2011.08.007

Guidi, M., Kumar, A., and Foster, T. C. (2015a). Impaired attention and synaptic senescence of the prefrontal cortex involves redox regulation of NMDA receptors. J. Neurosci. 35, 3966-3977. doi: 10.1523/JNEUROSCI.3523-14.2015

Guidi, M., Rani, A., Karic, S., Severance, B., Kumar, A., and Foster, T. C. (2015b). Contribution of N-methyl-D-aspartate receptors to attention and episodic spatial memory during senescence. Neurobiol. Learn. Mem. 125, 36-46. doi: 10.1016/j.nlm.2015.07.015

Hallett, P. J., Spoelgen, R., Hyman, B. T., Standaert, D. G., and Dunah, A. W. (2006). Dopamine D1 activation potentiates striatal NMDA receptors by tyrosine phosphorylation-dependent subunit trafficking. J. Neurosci. 26, 4690-4700. doi: 10.1523/JNEUROSCI.0792-06.2006

Hardingham, G. E., Fukunaga, Y., and Bading, H. (2002). Extrasynaptic NMDARs oppose synaptic NMDARs by triggering CREB shut-off and cell death pathways. Nat. Neurosci. 5, 405-414. doi: 10.1038/nn835

Haxaire, C., Turpin, F. R., Potier, B., Kervern, M., Sinet, P. M., Barbanel, G., et al. (2012). Reversal of age-related oxidative stress prevents hippocampal synaptic plasticity deficits by protecting $\mathrm{d}$-serine-dependent NMDA receptor activation. Aging Cell 11, 336-344. doi: 10.1111/j.1474-9726.2012.00792.x

Hayashi, Y., Ishibashi, H., Hashimoto, K., and Nakanishi, H. (2006). Potentiation of the NMDA receptor-mediated responses through the activation of the glycine site by microglia secreting soluble factors. Glia 53, 660-668. doi: 10.1002/glia.20322

Heidinger, V., Manzerra, P., Wang, X. Q., Strasser, U., Yu, S. P., Choi, D. W., et al. (2002). Metabotropic glutamate receptor 1-induced upregulation of NMDA receptor current: mediation through the Pyk $2 / \mathrm{Src}$-family kinase pathway in cortical neurons. J. Neurosci. 22, 5452-5461.

Hofmann, S. G., Otto, M. W., Pollack, M. H., and Smits, J. A. (2015). D-cycloserine augmentation of cognitive behavioral therapy for anxiety disorders: an update. Curr. Psychiatry Rep. 17:532. doi: 10.1007/s11920-014-0532-2

Hollmann, M., and Heinemann, S. (1994). Cloned glutamate receptors. Annu. Rev. Neurosci. 17, 31-108. doi: 10.1146/annurev.ne.17.030194.000335

Hood, W. F., Compton, R. P., and Monahan, J. B. (1989). D-cycloserine: a ligand for the N-methyl-D-aspartate coupled glycine receptor has partial agonist characteristics. Neurosci. Lett. 98, 91-95. doi: 10.1016/0304-3940(89) 90379-0

Horio, M., Mori, H., and Hashimoto, K. (2013). Is D-cycloserine a prodrug for D-serine in the brain? Biol. Psychiatry 73, e33-e34. doi: 10.1016/j.biopsych.2012.07.013

Huang, Y. J., Lin, C. H., Lane, H. Y., and Tsai, G. E. (2012). NMDA Neurotransmission dysfunction in behavioral and psychological symptoms of Alzheimer's disease. Curr. Neuropharmacol. 10, 272-285. doi: $10.2174 / 157015912803217288$

Ingram, D. K., Garofalo, P., Spangler, E. L., Mantione, C. R., Odano, I., and London, E. D. (1992). Reduced density of NMDA receptors and increased sensitivity to dizocilpine-induced learning impairment in aged rats. Brain Res. 580, 273-280. doi: 10.1016/0006-8993(92)90954-8

Jain, S., Kumar, C. H., Suranagi, U. D., and Mediratta, P. K. (2011). Protective effect of $\mathrm{N}$-acetylcysteine on bisphenol A-induced cognitive dysfunction and oxidative stress in rats. Food Chem. Toxicol. 49, 1404-1409. doi: 10.1016/j.fct.2011.03.032

Jayalakshmi, K., Singh, S. B., Kalpana, B., Sairam, M., Muthuraju, S., and Ilavazhagan, G. (2007). N-acetyl cysteine supplementation prevents impairment of spatial working memory functions in rats following exposure to hypobaric hypoxia. Physiol. Behav. 92, 643-650. doi: 10.1016/j.physbeh.2007.05.051

Johnson, J. W., and Ascher, P. (1987). Glycine potentiates the NMDA response in cultured mouse brain neurons. Nature 325, 529-531. doi: 10.1038/ $325529 \mathrm{a} 0$

Junjaud, G., Rouaud, E., Turpin, F., Mothet, J. P., and Billard, J. M. (2006). Age-related effects of the neuromodulator D-serine on neurotransmission and synaptic potentiation in the CA1 hippocampal area of the rat. J. Neurochem. 98, 1159-1166. doi: 10.1111/j.1471-4159.2006.03944.x

Kelly, G. S. (1998). Clinical applications of N-acetylcysteine. Altern. Med. Rev. 3, 114-127.

Kemp, J. A., and Leeson, P. D. (1993). The glycine site of the NMDA receptor-five years on. Trends Pharmacol. Sci. 14, 20-25. doi: 10.1016/0165-6147(93)90108-V

Kito, S., Miyoshi, R., and Nomoto, T. (1990). Influence of age on NMDA receptor complex in rat brain studied by in vitro autoradiography. J. Histochem. Cytochem. 38, 1725-1731. doi: 10.1177/38.12.2147708

Kochlamazashvili, G., Bukalo, O., Senkov, O., Salmen, B., Gerardy-Schahn, R., Engel, A. K., et al. (2012). Restoration of synaptic plasticity and learning in young and aged NCAM-deficient mice by enhancing neurotransmission mediated by GluN2A-containing NMDA receptors. J. Neurosci. 32, 2263-2275. doi: 10.1523/JNEUROSCI.5103-11.2012

Kranjac, D., Koster, K. M., Kahn, M. S., Eimerbrink, M. J., Womble, B. M., Cooper, B. G., et al. (2013). Peripheral administration of D-cycloserine rescues memory consolidation following bacterial endotoxin exposure. Behav. Brain Res. 243, 38-43. doi: 10.1016/j.bbr.2012.12.053

Kuehl-Kovarik, M. C., Partin, K. M., and Magnusson, K. R. (2003). Acute dissociation for analyses of NMDA receptor function in cortical neurons during aging. J. Neurosci. Methods 129, 11-17. doi: 10.1016/S0165-0270(03)00196-1

Kumar, A., Bodhinathan, K., and Foster, T. C. (2009). Susceptibility to calcium dysregulation during brain aging. Front. Aging Neurosci. 1:2. doi: $10.3389 /$ neuro.24.002.2009

Kumar, A., and Foster, T. C. (2013). Linking redox regulation of NMDAR synaptic function to cognitive decline during aging. J. Neurosci. 33, 15710-15715. doi: 10.1523/JNEUROSCI.2176-13.2013

Kuriyama, K., Honma, M., Koyama, S., and Kim, Y. (2011). D-cycloserine facilitates procedural learning but not declarative learning in healthy humans: a randomized controlled trial of the effect of D-cycloserine and valproic acid on overnight properties in the performance of non-emotional memory tasks. Neurobiol. Learn. Mem. 95, 505-509. doi: 10.1016/j.nlm.2011.02.017 
Kutsuwada, T., Kashiwabuchi, N., Mori, H., Sakimura, K., Kushiya, E., Araki, K., et al. (1992). Molecular diversity of the NMDA receptor channel. Nature 358, 36-41. doi: $10.1038 / 358036 \mathrm{a} 0$

Labrie, V., and Roder, J. C. (2010). The involvement of the NMDA receptor $\mathrm{D}$-serine/glycine site in the pathophysiology and treatment of schizophrenia. Neurosci. Biobehav. Rev. 34, 351-372. doi: 10.1016/j.neubiorev.2009.08.002

Lanté, F., Meunier, J., Guiramand, J., M. De Jesus Ferreira, C., Cambonie, G., Aimar, R., et al. (2008). Late $\mathrm{N}$-acetylcysteine treatment prevents the deficits induced in the offspring of dams exposed to an immune stress during gestation. Hippocampus 18, 602-609. doi: 10.1002/hipo.20421

Lau, C. G., and Zukin, R. S. (2007). NMDA receptor trafficking in synaptic plasticity and neuropsychiatric disorders. Nat. Rev. Neurosci. 8, 413-426. doi: $10.1038 / \mathrm{nrn} 2153$

Laube, B., Kuhse, J., and Betz, H. (1998). Evidence for a tetrameric structure of recombinant NMDA receptors. J. Neurosci. 18, 2954-2961.

Laurie, D. J., Bartke, I., Schoepfer, R., Naujoks, K., and Seeburg, P. H. (1997). Regional, developmental and interspecies expression of the four NMDAR2 subunits, examined using monoclonal antibodies. Brain Res. Mol. Brain Res. 51, 23-32. doi: 10.1016/S0169-328X(97)00206-4

Laurie, D. J., and Seeburg, P. H. (1994). Regional and developmental heterogeneity in splicing of the rat brain NMDAR1 mRNA. J. Neurosci. 14, 3180-3194.

Law, A. J., Weickert, C. S., Webster, M. J., Herman, M. M., Kleinman, J. E., and Harrison, P. J. (2003a). Changes in NMDA receptor subunit mRNAs and cyclophilin mRNA during development of the human hippocampus. Ann. N.Y. Acad. Sci. 1003, 426-430. doi: 10.1196/annals.1300.043

Law, A. J., Weickert, C. S., Webster, M. J., Herman, M. M., Kleinman, J. E., and Harrison, P. J. (2003b). Expression of NMDA receptor NR1, NR2A and NR2B subunit mRNAs during development of the human hippocampal formation. Eur. J. Neurosci. 18, 1197-1205. doi: 10.1046/j.1460-9568.2003.02850.x

Lee, W. H., Kumar, A., Rani, A., and Foster, T. C. (2014). Role of antioxidant enzymes in redox regulation of $\mathrm{N}$-methyl-D-aspartate receptor function and memory in middle-aged rats. Neurobiol. Aging 35, 1459-1468. doi: 10.1016/j.neurobiolaging.2013.12.002

Lester, R. A., and Jahr, C. E. (1990). Quisqualate receptor-mediated depression of calcium currents in hippocampal neurons. Neuron 4, 741-749. doi: 10.1016/0896-6273(90)90200-Y

Lieberman, D. N., and Mody, I. (1994). Regulation of NMDA channel function by endogenous $\mathrm{Ca}^{(2+)}$-dependent phosphatase. Nature 369, 235-239. doi: $10.1038 / 369235 \mathrm{a} 0$

Lin, C. H., Huang, Y. J., Lin, C. J., Lane, H. Y., and Tsai, G. E. (2014). NMDA neurotransmission dysfunction in mild cognitive impairment and Alzheimer's disease. Curr. Pharm. Des. 20, 5169-5179. doi: $10.2174 / 1381612819666140110115603$

Lin, Y., Jover-Mengual, T., Wong, J., Bennett, M. V., and Zukin, R. S. (2006). PSD-95 and PKC converge in regulating NMDA receptor trafficking and gating. Proc. Natl. Acad. Sci. U.S.A. 103, 19902-19907. doi: 10.1073/pnas.0609 924104

Lipton, S. A., Choi, Y. B., Takahashi, H., Zhang, D., Li, W., Godzik, A., et al. (2002). Cysteine regulation of protein function-as exemplified by NMDA-receptor modulation. Trends Neurosci. 25, 474-480. doi: 10.1016/S0166-2236(02) 02245-2

Lisman, J. E., Fellous, J. M., and Wang, X. J. (1998). A role for NMDA-receptor channels in working memory. Nat. Neurosci. 1, 273-275. doi: 10.1038/1086

Liu, F., Day, M., Muñiz, L. C., Bitran, D., Arias, R., Revilla-Sanchez, R., et al. (2008b). Activation of estrogen receptor-beta regulates hippocampal synaptic plasticity and improves memory. Nat. Neurosci. 11, 334-343. doi: $10.1038 / \mathrm{nn} 2057$

Liu, P., Smith, P. F., and Darlington, C. L. (2008a). Glutamate receptor subunits expression in memory-associated brain structures: regional variations and effects of aging. Synapse 62, 834-841. doi: 10.1002/syn.20563

Liu, X. B., Murray, K. D., and Jones, E. G. (2004). Switching of NMDA receptor $2 \mathrm{~A}$ and $2 \mathrm{~B}$ subunits at thalamic and cortical synapses during early postnatal development. J. Neurosci. 24, 8885-8895. doi: 10.1523/JNEUROSCI.247604.2004

Loerch, P. M., Lu, T., Dakin, K. A., Vann, J. M., Isaacs, A., Geula, C., et al. (2008). Evolution of the aging brain transcriptome and synaptic regulation. PLOS ONE 3:e3329. doi: 10.1371/journal.pone.0003329
Low, C. M., and Wee, K. S. (2010). New insights into the not-so-new NR3 subunits of N-methyl-D-aspartate receptor: localization, structure, and function. Mol. Pharmacol. 78, 1-11. doi: 10.1124/mol.110.064006

Madden, K. (2002). NMDA receptor antagonists and glycine site NMDA antagonists. Curr. Med. Res. Opin. 18(Suppl. 2), s27-s31. doi: $10.1185 / 030079902125000705$

Magnusson, K. R. (1995). Differential effects of aging on binding sites of the activated NMDA receptor complex in mice. Mech. Ageing Dev. 84, 227-243. doi: 10.1016/0047-6374(95)01658-9

Magnusson, K. R. (1998a). The aging of the NMDA receptor complex. Front. Biosci. 3, e70-e80.

Magnusson, K. R. (1998b). Aging of glutamate receptors: correlations between binding and spatial memory performance in mice. Mech. Ageing Dev. 104, 227-248. doi: 10.1016/S0047-6374(98)00076-1

Magnusson, K. R. (2000). Declines in mRNA expression of different subunits may account for differential effects of aging on agonist and antagonist binding to the NMDA receptor. J. Neurosci. 20, 1666-1674.

Magnusson, K. R. (2001). Influence of diet restriction on NMDA receptor subunits and learning during aging. Neurobiol. Aging 22, 613-627. doi: 10.1016/S01974580(00)00258-X

Magnusson, K. R. (2012). Aging of the NMDA receptor: from a mouse's point of view. Future Neurol. 7, 627-637. doi: 10.2217/fnl.12.54

Magnusson, K. R., Bai, L., and Zhao, X. (2005). The effects of aging on different C-terminal splice forms of the zetal(NR1) subunit of the N-methyld-aspartate receptor in mice. Brain Res. Mol. Brain Res. 135, 141-149. doi: 10.1016/j.molbrainres.2004.12.012

Magnusson, K. R., Brim, B. L., and Das, S. R. (2010). Selective vulnerabilities of N-methyl-D-aspartate (NMDA) receptors during brain aging. Front. Aging Neurosci. 2:11. doi: 10.3389/fnagi.2010.00011

Magnusson, K. R., and Cotman, C. W. (1993). Age-related changes in excitatory amino acid receptors in two mouse strains. Neurobiol. Aging 14, 197-206. doi: 10.1016/0197-4580(93)90001-R

Magnusson, K. R., Kresge, D., and Supon, J. (2006). Differential effects of aging on NMDA receptors in the intermediate versus the dorsal hippocampus. Neurobiol. Aging 27, 324-333. doi: 10.1016/j.neurobiolaging.2005.01.012

Magnusson, K. R., Scruggs, B., Zhao, X., and Hammersmark, R. (2007). Age-related declines in a two-day reference memory task are associated with changes in NMDA receptor subunits in mice. BMC Neurosci. 8:43. doi: 10.1186/14712202-8-43

Martin, S. J., Grimwood, P. D., and Morris, R. G. (2000). Synaptic plasticity and memory: an evaluation of the hypothesis. Annu. Rev. Neurosci. 23, 649-711. doi: 10.1146/annurev.neuro.23.1.649

Martínez, M., Hernández, A. I., and Martínez, N. (2000). N-Acetylcysteine delays age-associated memory impairment in mice: role in synaptic mitochondria. Brain Res. 855, 100-106. doi: 10.1016/S0006-8993(99)02349-5

Martínez Villayandre, B., Paniagua, M. A., Fernández-López, A., Chinchetru, M. A., and Calvo, P. (2004). Effect of vitamin E treatment on N-methyl-Daspartate receptor at different ages in the rat brain. Brain Res. 1028, 148-155. doi: 10.1016/j.brainres.2004.09.008

Massey, P. V., Johnson, B. E., Moult, P. R., Auberson, Y. P., Brown, M. W., Molnar, E., et al. (2004). Differential roles of NR2A and NR2B-containing NMDA receptors in cortical long-term potentiation and long-term depression. J. Neurosci. 24, 7821-7828. doi: 10.1523/JNEUROSCI.1697-04.2004

Matute, C. (2007). Interaction between glutamate signalling and immune attack in damaging oligodendrocytes. Neuron Glia Biol. 3, 281-285. doi: 10.1017/S1740925X08000033

Meguro, H., Mori, H., Araki, K., Kushiya, E., Kutsuwada, T., Yamazaki, M., et al. (1992). Functional characterization of a heteromeric NMDA receptor channel expressed from cloned cDNAs. Nature 357, 70-74. doi: 10.1038/ 357070a0

Mesches, M. H., Gemma, C., Veng, L. M., Allgeier, C., Young, D. A., Browning, M. D., et al. (2004). Sulindac improves memory and increases NMDA receptor subunits in aged Fischer 344 rats. Neurobiol. Aging 25, 315-324. doi: 10.1016/S0197-4580(03)00116-7

Minkeviciene, R., Banerjee, P., and Tanila, H. (2004). Memantine improves spatial learning in a transgenic mouse model of Alzheimer's disease. J. Pharmacol. Exp. Ther. 311, 677-682. doi: 10.1124/jpet.104.071027 
Miya, K., Inoue, R., Takata, Y., Abe, M., Natsume, R., Sakimura, K., et al. (2008). Serine racemase is predominantly localized in neurons in mouse brain. J. Comp. Neurol. 510, 641-654. doi: 10.1002/cne.21822

Miyoshi, R., Kito, S., Doudou, N., and Nomoto, T. (1991). Influence of age on Nmethyl-D-aspartate antagonist binding sites in the rat brain studied by in vitro autoradiography. Synapse 8, 212-217. doi: 10.1002/syn.890080307

Monaghan, D. T., Irvine, M. W., Costa, B. M., Fang, G., and Jane, D. E. (2012). Pharmacological modulation of NMDA receptor activity and the advent of negative and positive allosteric modulators. Neurochem. Int. 61, 581-592. doi: 10.1016/j.neuint.2012.01.004

Mondadori, C., and Weiskrantz, L. (1993). NMDA receptor blockers facilitate and impair learning via different mechanisms. Behav. Neural Biol. 60, 205-210. doi: 10.1016/0163-1047(93)90371-N

Mondadori, C., Weiskrantz, L., Buerki, H., Petschke, F., and Fagg, G. E. (1989). NMDA receptor antagonists can enhance or impair learning performance in animals. Exp. Brain Res. 75, 449-456. doi: 10.1007/BF00249896

Monyer, H., Burnashev, N., Laurie, D. J., Sakmann, B., and Seeburg, P. H. (1994). Developmental and regional expression in the rat brain and functional properties of four NMDA receptors. Neuron 12, 529-540. doi: 10.1016/08966273(94)90210-0

Monyer, H., Sprengel, R., Schoepfer, R., Herb, A., Higuchi, M., Lomeli, H., et al. (1992). Heteromeric NMDA receptors: molecular and functional distinction of subtypes. Science 256, 1217-1221. doi: 10.1126/science.256.5060.1217

Moriguchi, S., Mizoguchi, Y., Tomimatsu, Y., Hayashi, Y., Kadowaki, T., Kagamiishi, Y., et al. (2003). Potentiation of NMDA receptor-mediated synaptic responses by microglia. Brain research. Mol. Brain Res. 119, 160-169. doi: 10.1016/j.molbrainres.2003.09.007

Moriyoshi, K., Masu, M., Ishii, T., Shigemoto, R., Mizuno, N., and Nakanishi, S. (1991). Molecular cloning and characterization of the rat NMDA receptor. Nature 354, 31-37. doi: 10.1038/354031a0

Morris, R. G. (1989). Synaptic plasticity and learning: selective impairment of learning rats and blockade of long-term potentiation in vivo by the N-methylD-aspartate receptor antagonist AP5. J. Neurosci. 9, 3040-3057.

Morris, R. G., Anderson, E., Lynch, G. S., and Baudry, M. (1986). Selective impairment of learning and blockade of long-term potentiation by an $\mathrm{N}$ methyl-D-aspartate receptor antagonist, AP5. Nature 319, 774-776. doi: 10.1038/319774a0

Morrison, J. H., and Baxter, M. G. (2012). The ageing cortical synapse: hallmarks and implications for cognitive decline. Nat. Rev. Neurosci. 13, 240-250. doi: 10.1038/nrn3200

Mothet, J. P., Parent, A. T., Wolosker, H., Brady, R. O. Jr., Linden, D. J., Ferris, C. D., et al. (2000). D-serine is an endogenous ligand for the glycine site of the Nmethyl-D-aspartate receptor. Proc. Natl. Acad. Sci. U.S.A. 97, 4926-4931. doi: 10.1073/pnas.97.9.4926

Mothet, J. P., Rouaud, E., Sinet, P. M., Potier, B., Jouvenceau, A., Dutar, P., et al. (2006). A critical role for the glial-derived neuromodulator D-serine in the agerelated deficits of cellular mechanisms of learning and memory. Aging Cell 5, 267-274. doi: 10.1111/j.1474-9726.2006.00216.x

Nishikawa, T. (2005). Metabolism and functional roles of endogenous D-serine in mammalian brains. Biol. Pharm. Bull. 28, 1561-1565. doi: 10.1248/bpb.28.1561

Norberg, M. M., Krystal, J. H., and Tolin, D. F. (2008). A meta-analysis of D-cycloserine and the facilitation of fear extinction and exposure therapy. Biol. Psychiatry 63, 1118-1126. doi: 10.1016/j.biopsych.2008. 01.012

Norris, C. M., Halpain, S., and Foster, T. C. (1998). Alterations in the balance of protein kinase/phosphatase activities parallel reduced synaptic strength during aging. J. Neurophysiol. 80, 1567-1570.

Ohno, M., and Watanabe, S. (1996). D-cycloserine, a glycine site agonist, reverses working memory failure by hippocampal muscarinic receptor blockade in rats. Eur. J. Pharmacol. 318, 267-271. doi: 10.1016/S0014-2999(96)00907-7

Ontl, T., Xing, Y., Bai, L., Kennedy, E., Nelson, S., Wakeman, M., et al. (2004). Development and aging of N-methyl-D-aspartate receptor expression in the prefrontal/frontal cortex of mice. Neuroscience 123, 467-479. doi: 10.1016/j.neuroscience.2003.09.006

Otte, D. M., Sommersberg, B., Kudin, A., Guerrero, C., Albayram, O., Filiou, M. D., et al. (2011). N-acetyl cysteine treatment rescues cognitive deficits induced by mitochondrial dysfunction in G72/G30 transgenic mice. Neuropsychopharmacology 36, 2233-2243. doi: 10.1038/npp.2011.109
Pallàs, M., and Camins, A. (2006). Molecular and biochemical features in Alzheimer's disease. Curr. Pharm. Des. 12, 4389-4408. doi: 10.2174/138161206778792967

Panatier, A., Theodosis, D. T., Mothet, J. P., Touquet, B., Pollegioni, L., Poulain, D. A., et al. (2006). Glia-derived D-serine controls NMDA receptor activity and synaptic memory. Cell 125, 775-784. doi: 10.1016/j.cell.2006.02.051

Parihar, M. S., Kunz, E. A., and Brewer, G. J. (2008). Age-related decreases in $\mathrm{NAD}(\mathrm{P}) \mathrm{H}$ and glutathione cause redox declines before ATP loss during glutamate treatment of hippocampal neurons. J. Neurosci. Res. 86, 2339-2352. doi: 10.1002/jnr.21679

Parsons, C. G., Stöffler, A., and Danysz, W. (2007). Memantine: a NMDA receptor antagonist that improves memory by restoration of homeostasis in the glutamatergic system-too little activation is bad, too much is even worse. Neuropharmacology 53, 699-723. doi: 10.1016/j.neuropharm.2007.07.013

Pietá Dias, C., Martins de Lima, M. N., Presti-Torres, J., Dornelles, A., Garcia, V. A., Siciliani Scalco, F., et al. (2007). Memantine reduces oxidative damage and enhances long-term recognition memory in aged rats. Neuroscience 146, 1719-1725. doi: 10.1016/j.neuroscience.2007.03.018

Pitkänen, M., Sirviö, J., Lahtinen, H., Koivisto, E., and Riekkinen, P. (1994). dCycloserine, a partial agonist at the glycine site, enhances the excitability of dentate granule cells in vivo in rats. Eur. J. Pharmacol. 253, 125-129. doi: 10.1016/0014-2999(94)90766-8

Pittaluga, A., Fedele, E., Risiglione, C., and Raiteri, M. (1993). Age-related decrease of the NMDA receptor-mediated noradrenaline release in rat hippocampus and partial restoration by D-cycloserine. Eur. J. Pharmacol. 231, 129-134. doi: 10.1016/0014-2999(93)90693-C

Poon, H. F., Calabrese, V., Calvani, M., and Butterfield, D. A. (2006). Proteomics analyses of specific protein oxidation and protein expression in aged rat brain and its modulation by L-acetylcarnitine: insights into the mechanisms of action of this proposed therapeutic agent for CNS disorders associated with oxidative stress. Antioxid. Redox Signal. 8, 381-394. doi: 10.1089/ars.2006.8.381

Priestley, T., Laughton, P., Myers, J., Le Bourdellés, B., Kerby, J., and Whiting, P. J. (1995). Pharmacological properties of recombinant human N-methylD-aspartate receptors comprising NR1a/NR2A and NR1a/NR2B subunit assemblies expressed in permanently transfected mouse fibroblast cells. Mol. Pharmacol. 48, 841-848.

Raman, I. M., Tong, G., and Jahr, C. E. (1996). Beta-adrenergic regulation of synaptic NMDA receptors by cAMP-dependent protein kinase. Neuron 16, 415-421. doi: 10.1016/S0896-6273(00)80059-8

Reid, M., and Jahoor, F. (2001). Glutathione in disease. Curr. Opin. Clin. Nutr. Metab. Care 4, 65-71. doi: 10.1097/00075197-200101000-00012

Reisberg, B., Doody, R., Stöffler, A., Schmitt, F., Ferris, S., and Möbius, H. J. (2003). Memantine in moderate-to-severe Alzheimer's disease. N. Engl. J. Med. 348, 1333-1341. doi: 10.1056/NEJMoa013128

Ren, J., Li, X., Zhang, X., Li, M., Wang, Y., and Ma, Y. (2013). The effects of intra-hippocampal microinfusion of D-cycloserine on fear extinction, and the expression of NMDA receptor subunit NR2B and neurogenesis in the hippocampus in rats. Prog. Neuropsychopharmacol. Biol. Psychiatry 44, 257-264. doi: 10.1016/j.pnpbp.2013.02.017

Reynolds, I. J., Murphy, S. N., and Miller, R. J. (1987). 3H-labeled MK-801 binding to the excitatory amino acid receptor complex from rat brain is enhanced by glycine. Proc. Natl. Acad. Sci. U.S.A. 84, 7744-7748. doi: 10.1073/pnas.84.21.7744

Robillard, J. M., Gordon, G. R., Choi, H. B., Christie, B. R., and MacVicar, B. A. (2011). Glutathione restores the mechanism of synaptic plasticity in aged mice to that of the adult. PLOS ONE 6:e20676. doi: 10.1371/journal.pone. 0020676

Rodrigues, F. S., Souza, M. A., Magni, D. V., Ferreira, A. P., Mota, B. C., Cardoso, A. M., et al. (2013). N-acetylcysteine prevents spatial memory impairment induced by chronic early postnatal glutaric acid and lipopolysaccharide in rat pups. PLoS ONE 8:e78332. doi: 10.1371/journal.pone.0078332

Rosenberg, D., Kartvelishvily, E., Shleper, M., Klinker, C. M., Bowser, M. T., and Wolosker, H. (2010). Neuronal release of D-serine: a physiological pathway controlling extracellular D-serine concentration. FASEB J. 24, 2951-2961. doi: 10.1096/fj.09-147967

Rosi, S., Ramirez-Amaya, V., Hauss-Wegrzyniak, B., and Wenk, G. L. (2004). Chronic brain inflammation leads to a decline in hippocampal NMDA-R1 receptors. J. Neuroinflammation 1:12. doi: 10.1186/1742-2094-1-12 
Rosi, S., Vazdarjanova, A., Ramirez-Amaya, V., Worley, P. F., Barnes, C. A., and Wenk, G. L. (2006). Memantine protects against LPS-induced neuroinflammation, restores behaviorally-induced gene expression and spatial learning in the rat. Neuroscience 142, 1303-1315. doi: 10.1016/j.neuroscience.2006.08.017

Rouaud, E., and Billard, J. M. (2003). D-cycloserine facilitates synaptic plasticity but impairs glutamatergic neurotransmission in rat hippocampal slices. $\mathrm{Br}$. J. Pharmacol. 140, 1051-1056. doi: 10.1038/sj.bjp.0705541

Sanz-Clemente, A., Nicoll, R. A., and Roche, K. W. (2013). Diversity in NMDA receptor composition: many regulators, many consequences. Neuroscientist 19, 62-75. doi: $10.1177 / 1073858411435129$

Scarpini, E., Scheltens, P., and Feldman, H. (2003). Treatment of Alzheimer's disease: current status and new perspectives. Lancet. Neurol. 2, 539-547. doi: 10.1016/S1474-4422(03)00502-7

Schell, M. J., Molliver, M. E., and Snyder, S. H. (1995). D-serine, an endogenous synaptic modulator: localization to astrocytes and glutamate-stimulated release. Proc. Natl. Acad. Sci. U.S.A. 92, 3948-3952. doi: 10.1073/pnas.92.9.3948

Schneider, L. S., Dagerman, K. S., Higgins, J. P., and McShane, R. (2011). Lack of evidence for the efficacy of memantine in mild Alzheimer disease. Arch. Neurol. 68, 991-998. doi: 10.1001/archneurol.2011.69

Schüler, T., Mesic, I., Madry, C., Bartholomäus, I., and Laube, B. (2008). Formation of NR1/NR2 and NR1/NR3 heterodimers constitutes the initial step in N-methyl-D-aspartate receptor assembly. J. Biol. Chem. 283, 37-46. doi: 10.1074/jbc.M703539200

Scott, D. B., Blanpied, T. A., Swanson, G. T., Zhang, C., and Ehlers, M. D. (2001). An NMDA receptor ER retention signal regulated by phosphorylation and alternative splicing. J. Neurosci. 21, 3063-3072.

Serra, M., Ghiani, C. A., Foddi, M. C., Motzo, C., and Biggio, G. (1994). NMDA receptor function is enhanced in the hippocampus of aged rats. Neurochem. Res. 19, 483-487. doi: 10.1007/BF00967328

Shimada, A., Mukhin, A., Ingram, D. K., and London, E. D. (1997). N-methyl-Daspartate receptor binding in brains of rats at different ages. Neurobiol. Aging 18, 329-333. doi: 10.1016/S0197-4580(97)80315-6

Shipton, O. A., and Paulsen, O. (2014). GluN2A and GluN2B subunit-containing NMDA receptors in hippocampal plasticity. Philos. Trans. R. Soc. Lond. B Biol. Sci. 369, 20130163. doi: 10.1098/rstb.2013.0163

Snyder, E. M., Nong, Y., Almeida, C. G., Paul, S., Moran, T., Choi, E. Y., et al. (2005). Regulation of NMDA receptor trafficking by amyloid-beta. Nat. Neurosci. 8, 1051-1058. doi: 10.1038/nn1503

Soleimani Asl, S., Saifi, B., Sakhaie, A., Zargooshnia, S., and Mehdizadeh, M. (2015). Attenuation of ecstasy-induced neurotoxicity by $\mathrm{N}$-acetylcysteine. Metab. Brain Dis. 30, 171-181. doi: 10.1007/s11011-014-9598-0

Sonntag, W. E., Bennett, S. A., Khan, A. S., Thornton, P. L., Xu, X., Ingram, R. L., et al. (2000). Age and insulin-like growth factor-1 modulate N-methyl-Daspartate receptor subtype expression in rats. Brain Res. Bull. 51, 331-338. doi: 10.1016/S0361-9230(99)00259-2

Steullet, P., Cabungcal, J. H., Monin, A., Dwir, D., O’Donnell, P., Cuenod, M., et al. (2014). Redox dysregulation, neuroinflammation, and NMDA receptor hypofunction: a "central hub" in schizophrenia pathophysiology? Schizophr. Res. doi: 10.1016/j.schres.2014.06.021. [Epub ahead of print].

Sucher, N. J., Akbarian, S., Chi, C. L., Leclerc, C. L., Awobuluyi, M., Deitcher, D. L., et al. (1995). Developmental and regional expression pattern of a novel NMDA receptor-like subunit (NMDAR-L) in the rodent brain. J. Neurosci. 15, 6509-6520.

Sucher, N. J., and Lipton, S. A. (1991). Redox modulatory site of the NMDA receptor-channel complex: regulation by oxidized glutathione. J. Neurosci. Res. 30, 582-591. doi: 10.1002/jnr.490300316

Sullivan, J. M., Traynelis, S. F., Chen, H. S., Escobar, W., Heinemann, S. F., and Lipton, S. A. (1994). Identification of two cysteine residues that are required for redox modulation of the NMDA subtype of glutamate receptor. Neuron 13, 929-936. doi: 10.1016/0896-6273(94)90258-5

Tamaru, M., Yoneda, Y., Ogita, K., Shimizu, J., and Nagata, Y. (1991). Agerelated decreases of the N-methyl-D-aspartate receptor complex in the rat cerebral cortex and hippocampus. Brain Res. 542, 83-90. doi: 10.1016/00068993(91)91001-H

Tang, L. H., and Aizenman, E. (1993). The modulation of N-methyl-D-aspartate receptors by redox and alkylating reagents in rat cortical neurones in vitro. J. Physiol. 465, 303-323. doi: 10.1113/jphysiol.1993.sp019678
Thakurta, I. G., Banerjee, P., Bagh, M. B., Ghosh, A., Sahoo, A., Chattopadhyay, S., et al. (2014). Combination of $\mathrm{N}$-acetylcysteine, alpha-lipoic acid and alpha-tocopherol substantially prevents the brain synaptosomal alterations and memory and learning deficits of aged rats. Exp. Gerontol. 50, 19-25. doi: 10.1016/j.exger.2013.11.008

Thompson, L. T., Moskal, J. R., and Disterhoft, J. F. (1992). Hippocampusdependent learning facilitated by a monoclonal antibody or D-cycloserine. Nature 359, 638-641. doi: 10.1038/359638a0

Topic, B., Willuhn, I., Palomero-Gallagher, N., Zilles, K., Huston, J. P., and Hasenöhrl, R. U. (2007). Impaired maze performance in aged rats is accompanied by increased density of NMDA, 5-HT1A, and alpha-adrenoceptor binding in hippocampus. Hippocampus 17, 68-77. doi: 10.1002/hipo. 20246

Traynelis, S. F., Wollmuth, L. P., McBain, C. J., Menniti, F. S., Vance, K. M., Ogden, K. K., et al. (2010). Glutamate receptor ion channels: structure, regulation, and function. Pharmacol. Rev. 62, 405-496. doi: 10.1124/pr.109.002451

Turpin, F. R., Potier, B., Dulong, J. R., Sinet, P. M., Alliot, J., Oliet, S. H., et al. (2011). Reduced serine racemase expression contributes to age-related deficits in hippocampal cognitive function. Neurobiol. Aging 32, 1495-1504. doi: 10.1016/j.neurobiolaging.2009.09.001

Vanhoutte, P., and Bading, H. (2003). Opposing roles of synaptic and extrasynaptic NMDA receptors in neuronal calcium signalling and BDNF gene regulation. Curr. Opin. Neurobiol. 13, 366-371. doi: 10.1016/S0959-4388(03)00073-4

Vicini, S., Wang, J. F., Li, J. H., Zhu, W. J., Wang, Y. H., Luo, J. H., et al. (1998). Functional and pharmacological differences between recombinant $\mathrm{N}$-methylD-aspartate receptors. J. Neurophysiol. 79, 555-566.

Wang, L. Y., Orser, B. A., Brautigan, D. L., and MacDonald, J. F. (1994). Regulation of NMDA receptors in cultured hippocampal neurons by protein phosphatases 1 and 2A. Nature 369, 230-232. doi: 10.1038/369230a0

Watanabe, M., Inoue, Y., Sakimura, K., and Mishina, M. (1993a). Distinct spatio-temporal distributions of the NMDA receptor channel subunit mRNAs in the brain. Ann. N.Y. Acad. Sci. 707, 463-466. doi: 10.1111/j.17496632.1993.tb38099.x

Watanabe, M., Inoue, Y., Sakimura, K., and Mishina, M. (1993b). Distinct distributions of five N-methyl-D-aspartate receptor channel subunit mRNAs in the forebrain. J. Comp. Neurol. 338, 377-390. doi: 10.1002/cne.903 380305

Wenk, G. L., and Barnes, C. A. (2000). Regional changes in the hippocampal density of AMPA and NMDA receptors across the lifespan of the rat. Brain Res. 885, 1-5. doi: 10.1016/S0006-8993(00)02792-X

Wenk, G. L., Walker, L. C., Price, D. L., and Cork, L. C. (1991). Loss of NMDA, but not GABA-A, binding in the brains of aged rats and monkeys. Neurobiol. Aging 12, 93-98. doi: 10.1016/0197-4580(91)90047-N

Williams, S. M., Diaz, C. M., Macnab, L. T., Sullivan, R. K., and Pow, D. V. (2006). Immunocytochemical analysis of D-serine distribution in the mammalian brain reveals novel anatomical compartmentalizations in glia and neurons. Glia 53, 401-411. doi: 10.1002/glia.20300

Wolosker, H. (2011). Serine racemase and the serine shuttle between neurons and astrocytes. Biochim. Biophys. Acta 1814, 1558-1566. doi: 10.1016/j.bbapap.2011.01.001

Wolosker, H., Blackshaw, S., and Snyder, S. H. (1999a). Serine racemase: a glial enzyme synthesizing D-serine to regulate glutamate-N-methyl-Daspartate neurotransmission. Proc. Natl. Acad. Sci. U.S.A. 96, 13409-13414. doi: 10.1073/pnas.96.23.13409

Wolosker, H., and Mori, H. (2012). Serine racemase: an unconventional enzyme for an unconventional transmitter. Amino Acids 43, 1895-1904. doi: 10.1007/s00726-012-1370-3

Wolosker, H., Sheth, K. N., Takahashi, M., Mothet, J. P., Brady, R. O. Jr., Ferris, C. D., et al. (1999b). Purification of serine racemase: biosynthesis of the neuromodulator D-serine. Proc. Natl. Acad. Sci. U.S.A. 96, 721-725. doi: 10.1073/pnas.96.2.721

$\mathrm{Wu}, \mathrm{S}$., and Barger, S. W. (2004). Induction of serine racemase by inflammatory stimuli is dependent on AP-1. Ann. N.Y. Acad. Sci. 1035, 133-146. doi: 10.1196/annals.1332.009

Wu, S. Z., Bodles, A. M., Porter, M. M., Griffin, W. S., Basile, A. S., and Barger, S. W. (2004). Induction of serine racemase expression and D-serine release from microglia by amyloid beta-peptide. J. Neuroinflammation 1:2. doi: $10.1186 / 1742-2094-1-2$ 
Wyllie, D. J., Livesey, M. R., and Hardingham, G. E. (2013). Influence of GluN2 subunit identity on NMDA receptor function. Neuropharmacology 74, 4-17. doi: 10.1016/j.neuropharm.2013.01.016

Yaka, R., Biegon, A., Grigoriadis, N., Simeonidou, C., Grigoriadis, S., Alexandrovich, A. G., et al. (2007). D-cycloserine improves functional recovery and reinstates long-term potentiation (LTP) in a mouse model of closed head injury. FASEB J. 21, 2033-2041. doi: 10.1096/fj.06-7856com

Yoshikawa, M., Takayasu, N., Hashimoto, A., Sato, Y., Tamaki, R., Tsukamoto, H., et al. (2007). The serine racemase mRNA is predominantly expressed in rat brain neurons. Arch. Histol. Cytol. 70, 127-134. doi: 10.1679/aohc. 70.127

Zamzow, D. R., Elias, V., Shumaker, M., Larson, C., and Magnusson, K. R. (2013). An increase in the association of GluN2B containing NMDA receptors with membrane scaffolding proteins was related to memory declines during aging. J. Neurosci. 33, 12300-12305. doi: 10.1523/JNEUROSCI.0312-13.2013

Zhao, X., Rosenke, R., Kronemann, D., Brim, B., Das, S. R., Dunah, A. W., et al. (2009). The effects of aging on N-methyl-d-aspartate receptor subunits in the synaptic membrane and relationships to long-term spatial memory. Neuroscience 162, 933-945. doi: 10.1016/j.neuroscience.2009. 05.018
Zhu, S., and Paoletti, P. (2015). Allosteric modulators of NMDA receptors: multiple sites and mechanisms. Curr. Opin. Pharmacol. 20C, 14-23. doi: 10.1016/j.coph.2014.10.009

Ziment, I. (1988). Acetylcysteine: a drug that is much more than a mucokinetic. Biomed. Pharmacother. 42, 513-519.

Zoladz, P. R., Campbell, A. M., Park, C. R., Schaefer, D., Danysz, W., and Diamond, D. M. (2006). Enhancement of long-term spatial memory in adult rats by the noncompetitive NMDA receptor antagonists, memantine and neramexane. Pharmacol. Biochem. Behav. 85, 298-306. doi: 10.1016/j.pbb.2006.08.011

Conflict of Interest Statement: The author declares that the research was conducted in the absence of any commercial or financial relationships that could be construed as a potential conflict of interest.

Copyright $\odot 2015$ Kumar. This is an open-access article distributed under the terms of the Creative Commons Attribution License (CC BY). The use, distribution or reproduction in other forums is permitted, provided the original author(s) or licensor are credited and that the original publication in this journal is cited, in accordance with accepted academic practice. No use, distribution or reproduction is permitted which does not comply with these terms. 